\title{
Escaping from the Resource Curse: Evidence from Botswana and the Rest of the World
}

\begin{abstract}
ATSUSHI IIMI*
It is commonly accepted that resource-rich economies tend to fail in accelerating growth because of various adverse effects of abundant natural resources, such as Dutch disease and rent seeking. Using the latest crosscountry data, this study empirically readdresses the question of whether resource abundance can contribute to growth. It finds that governance determines the extent to which the growth effects of resource wealth can materialize. In developing countries in particular, the quality of regulation, such as the predictability of changes of regulations, and anticorruption policies, such as transparency and accountability in the public sector, are most important for effective natural resource management and growth. The paper also attempts to interpret the theme and results in the context of Botswana, which is endowed with abundant natural resources but has experienced the most remarkable economic performance in the region. [JEL C31, O13, O21, Q32] IMF Staff Papers (2007) 54, 663-699. doi:10.1057/palgrave.imfsp.9450020
\end{abstract}

$\mathrm{t}$ is commonly accepted that natural-resource-abundant economies tend to grow less rapidly than resource-scarce economies - the phenomenon often

${ }^{*}$ The author is an economist with the Finance, Economics and Urban Development Department of the World Bank. The author is most grateful to Paul Heytens for his insightful suggestions throughout this research. He also thanks Aart Kraay and Marshall Mills, the Bank of Botswana, and the IMF's Office of the Executive Director for the Africa Group I Constituency for their helpful comments. Acknowledgments go as well to Robert Flood and two anonymous referees. 
referred to as the "resource curse." This paper recasts light on the question of whether abundant resources could stimulate economic development. Significantly, it might be true that many resource-rich countries have failed to transform their natural wealth into growth, but not all of them. For instance, Botswana, which is the most diamond-rich country in the world, has experienced remarkable growth over several decades.

One of the pioneer studies addressing the relationship between natural resource richness and economic growth is Sachs and Warner (1995). They find that developing countries with abundant primary resources are likely to grow slowly when initial income levels and differences in macroeconomic policies are controlled. Papyrakis and Gerlagh (2004), focusing on the transmission channels through which resource richness affects economic growth, show that the indirect, negative effects of macroeconomic policies, such as trade openness and educational investment, outweigh the direct, positive resource effects. Leite and Weidmann's (1999) evidence also supports the resource curse hypothesis. Capital-intensive resource industries tend to induce more corruption, hampering economic development.

To the contrary, Auty and Evans (1994) indicate that mineral exports are negatively correlated with growth, but only for the relatively mature mineralbased economies and only for certain periods. In addition, when focusing on people's standard of living - which is the ultimate development goalmeasured by life expectancy, infant mortality, and access to basic human needs, there is no indication that mineral economies are unduly suffering over the long term (Davis, 1995).

Theoretically, abundant natural resources could promote growth, because resource richness can give a "big push" to the economy through more investment in economic infrastructure and more rapid human capital development. Therefore, any resource-rich country must attain higher growth rates (Sachs and Warner, 1999; and Murphy, Shleifer, and Vishny, 2000). This is evident in the long-term history of resource-rich developed countries, such as Australia, Finland, and the United States (de Ferranti and others, 2001).

Various reasons have been put forward for failures to effectively transform natural resources to growth: (1) the Dutch disease, (2) insufficient economic diversification, (3) rent seeking and conflicts, (4) corruption and undermined political institutions, (5) overconfidence and loose economic policies, and (6) debt overhang.

First, one of the most alleged economic causes is the Dutch disease problem. In resource-exporting countries, sectors other than natural resources (typically manufacturing) are likely to suffer from real appreciation of the national currency, because natural resource earnings are in part absorbed by the domestic nontradables sector (for example, Corden and Neary, 1982). In the context of slow growth in Africa, Sachs and Warner (1997) interpret the estimated negative growth impact of natural resources to be part of the dynamic Dutch disease syndrome. However, the 
deteriorating terms of trade effect may remain open to argument (Darity, 1990; Bloch and Sapsford, 2000; and de Ferranti and others, 2001). On a simple correlation basis, it is rarely easy to see such a direct effect of large resource exports on the terms of trade-which is one of the major measures of external competitiveness (Figure 1), though there are other measures, such as factor costs, composition of exports, and national economic productivity.

Second, natural richness produces a highly concentrated structure of the economy and export revenues, which leads to economic vulnerability to exogenous shocks, resulting in slow growth (de Ferranti and others, 2001). The natural resource sector is generally capital-intensive and asset-specific. Extraction of minerals requires large, durable, location-specific investments (often referred to as site specificity). ${ }^{1}$ Once sited, the assets are almost immobile. Such investments in facilities and equipment tend to be unique to a particular mine and region (Masten and Crocker, 1985; and Joskow, 1987). Thus, natural resource development brings about few positive externalities to forward and backward industries (Sachs and Warner, 1995). For the same reasons, the learning-by-doing effect is not expected in this area, either.

Third, one of the most crucial reasons for resource-rich countries' stagnation, when attention is paid to the importance of governance in facilitating economic development, is that natural resource wealth sows the seeds of discord and conflict among domestic stakeholders, such as politicians, developers, local tribes, and citizens (also known as taxpayers). ${ }^{2}$ Large rents themselves may motivate rent-seeking activities and intensify domestic conflicts (Sala-i-Martin and Subramanian, 2003; Davis and Tilton, 2005; and Sørli, Gleditsch, and Strand, 2005). Barbier, Damania, and Léonard (2005) empirically examine how interest groups affected (forest) resource depletion through lobbying. Collier and Hoeffler (2005) indicate that counties with an abundance of natural resources are more prone to violent conflict. A formal model of political evolution for analyzing a resource-rich country shows that high resource dependency, concentration of government control over resources, and the government's ability to tax the opposition, such as private entrepreneurs, all inhibit the development of democracy and provoke insurrection. As a result, natural resources may impede economic growth (Shahnawaz and Nugent,

\footnotetext{
${ }^{1}$ To the contrary, in the agriculture sector, which is sometimes included in the natural resource sector (but not in the current analysis), this problem is interpreted to mean that too many people tend to be locked in low-skill-intensive natural-resource-based industries (Gylfason, 2006).

${ }^{2}$ For the argument on governance and growth, for example, see Tanzi and Davoodi (1997); Tanzi (1998); Burnside and Dollar (2000); Easterly, Levine, and Roodman (2004); and most recently, Glaeser and others (2004). Whereas Burnside and Dollar show that governance is a key in promoting growth in the context of foreign aid, Glaeser and others emphasize the risk of failing to measure institutional qualities and suggest that human capital is a more basic source of growth than political institutions.
} 
Figure 1. Natural Resource Abundance and Terms of Trade, 1998-2002

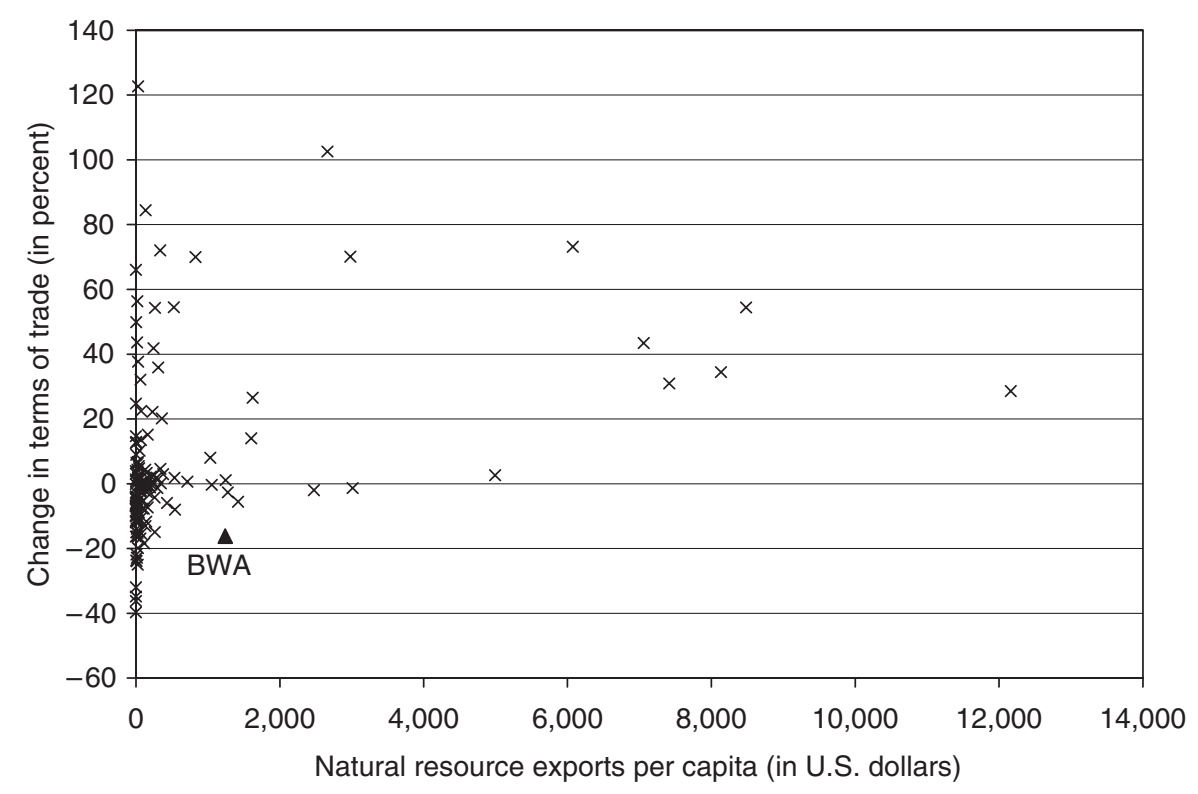

Note: The change in terms of trade is the simple average of annual growth rates for the period of 1998-2002. The original terms of trade data come from the World Economic Outlook database, which comprises data from a series of IMF Country Reports (e.g., Article IV Staff Reports and Statistical Appendix). The natural resource data are defined as the average resource exports divided by population, which cover metal ores/metal scrap (Standard International Trade Classification (SITC) 28), coal/coke briquettes (32), petroleum and products (33), gas natural/manufactured (34), nonmineral manufactures (66), nonferrous metals (68), and nonmonetary ore (97) in the World Integrated Trade Solution database.

2004). ${ }^{3}$ One implication of this situation is that because of their high earnings from natural resources, resource-dependent countries have less need for tax revenues and are therefore relatively relieved of accountability pressures.

Fourth, closely related to the above, resource rents tend to bring about not only conflict but also corruption, undermining political institutions. Leite and Weidmann (1999), modeling the effects of anticorruption policies, show that strengthened monitoring can reduce the steady-state shadow price of capital, producing a higher growth rate during the convergence. Empirically, it is shown that resource-dependent economies are more corruption-prone (Gylfason, 2001 and 2006; Sala-i-Martin and Subramanian, 2003; and

\footnotetext{
${ }^{3}$ The model also indicates that there is another equilibrium at which the government can induce the opposition to be cooperative by offering higher profit sharing, a lower tax rate, and higher capital spending on new resource discovery (the "repressive government" equilibrium). The "democracy" equilibrium may exist somewhere between the cooperative solution and the civil war outcome.
} 
Kronenberg, 2004). Natural resources that are traded on a black market, such coca and diamonds, are the extreme case, even though they do generate substantial economic gains in rural areas (Angrist and Kugler, 2005).

Fifth, natural resource abundance may also imbue policymakers with overconfidence in their economies and relieve them from appropriate but sometimes unpopular economic policy decisions. This is of particular importance from the viewpoint of government fiscal management. In developing countries, large resource rents may have the same negative impact as massive foreign aid inflows. As described in the aid fungibility literature (for example, Devarajan and Swarrop, 1998; and Gupta and others, 2003), resource wealth may relieve governments of tax collection pressures and reduce fiscal discipline. It is natural that populists tend to pander to the insatiable wish of citizens to reduce taxes. Bacon (2001) mentions that oil-producing countries are likely to charge lower domestic gasoline prices, implying that natural resource rents obtained from upstream royalties are subsidizing domestic downstream consumption.

The use of rents is critical in determining whether or not natural resources promote growth, as widely recognized (Davis and Tilton, 2002; and Davis and Tilton, 2005). An emerging consensus is that human capital investment could be an important channel to overcome the resource curse in the long run (Kronenberg, 2004; and Gylfason, 2006). In fact, counties with strong confidence that natural resources are the most important assets may be apt to neglect the development of human capital. In Latin America, high income inequality stemming from uneven distribution of resource returns has ended in failure to accumulate social and human capital, interfering with sustained growth and economic diversification (Leamer and others, 1999; de Ferranti and others, 2001; and Maloney, 2002). ${ }^{4}$

Finally, the resource curse may be explained mostly by the debt overhang of resource-rich countries in the 1970s. Manzano and Rigobon (2001) show that the 1980s debt crises triggered by a significant reduction in commodity prices can explain a large part of the negative effect of resource abundance on economic growth. Once this effect is accounted for, the estimated (nonagricultural) resource impact becomes insignificant. Rather, the stagnation may be associated with credit market imperfection. The finding is consistent with Auty and Evans (1994).

Botswana seems to be a good example to investigate these issues-Sachs and Warner (2001) identified as a marked exception to the resource curse in

\footnotetext{
${ }^{4}$ Income inequality is in general associated with slow economic growth. Banerjee and Duflo (2003) find that changes in inequality in any direction are associated with lower future growth rates. World Bank (2005) claims that inequalities resulting from the failure of capital and insurance markets as well as market imperfections for human capital development may also distort allocation and undermine economic growth. In many Latin American countries, opening to trade has increased inequality in earnings, and so there must be complementary measures to provide infrastructure and safety nets for stable growth.
} 
Figure 2. Botswana: Growth Contribution by Mining, 1980/81-2003/04 (Percent change)

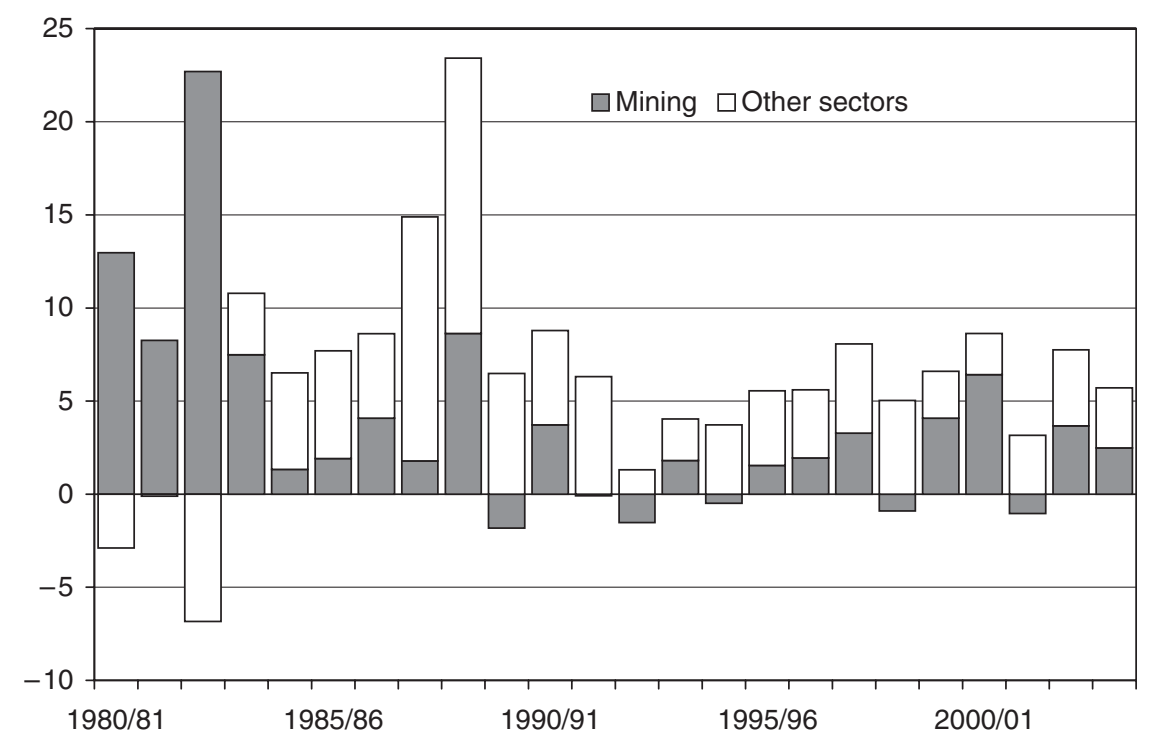

Note: The sectoral GDP data for Botswana are available in the Central Bank's Annual Report. The annual growth rates are calculated separately for the mining sector and the rest of the economy.

developing countries. Botswana is one of the most diamond-rich countries in the world and has experienced remarkable growth for several decades. It has been applauded for its good governance, political stability, and strong fiscal discipline (Acemoglu, Johnson, and Robinson, 2002). Botswana has also achieved one of the highest levels of education enrollment in the region. Its abundance of diamonds seems to have contributed significantly to Botswana's strong economic growth. The average growth rate since the 1980s has been 7.8 percent, about 40 percent of which can be explained by mining, though recent economic diversification has slightly reduced that contribution (Figure 2). Because of these backgrounds, the current paper will focus on Botswana when examining a worldwide trend and interpreting the empirical results.

\section{Recent Developments in Natural Resources and Governance in Botswana and the Rest of the World}

\section{Natural Resources and Growth}

Total world natural resource exports in 2002 amounted to over U.S.\$700 billion. This paper defines natural resources as nonagricultural minerals so as to focus on typically exhaustible natural resources. It includes not only 
petroleum products but also precious stones, such as diamonds. ${ }^{5}$ The total value of natural resource exports doubled for the period 1990-2002 (Figure 3). Particularly in recent years, a significant hike in international commodity prices has contributed to a boom in mineral exports. From the cross-country point of view, the distribution of world natural resource wealth is extremely skewed on a per capita basis (Figure 4). ${ }^{6}$ The five largest resource-rich countries contribute to half the global resource exports. About 70 percent of global resource exports come from the top 10 countries. These counties are generally oil and/or gas exporters in the Middle East or Northern Europe.

Botswana exported some \$2 billion of diamonds, nickel, copper, gold, and other minerals - over 80 percent of its total exports in 2002 (Figure 3). ${ }^{7}$ It is the 18th largest resource exporter among 161 countries for which data are available (Figure 4). Thanks to these resources, mostly diamonds, Botswana has experienced strong growth over the past three decades. However, such growth may not be sustainable. First, the capital-intensive mining sector does not provide many employment opportunities. Although mining production contributed 40 percent to GDP (Figure 5), it absorbed only 4 percent of total employment (Figure 6). ${ }^{8}$ Regardless of the government's efforts to diversify the economy, developing the nontraditional industries has been challenging (Figure 5). ${ }^{9}$ In that sense, as Sachs and Warner (1995) hypothesized, overly specific and intensified capital investment in the primary sector has restrained Botswana from benefiting from forward and backward linkages and labor market externalities. ${ }^{10}$

Second, geographical characteristics, such as lack of access to the sea, also make it harder to relate resource abundance to growth. Because natural resources are usually exported by sea, landlocked countries have extremely high shipping costs. Significantly, about one-third of sub-Saharan African countries, like Botswana, are landlocked (Sachs and Warner, 1997). Bloom, Canning, and Sevilla (2003) find that the proximity of land to the coast has a positive impact on national income and a high air temperature has a negative

\footnotetext{
${ }^{5}$ This paper defines natural resources as fuel, metal, nonferrous metals, and precious stones, according to the Standard International Trade Classification (SITC) version 3 category. More specifically, natural resource exports correspond to these SITC categories: 28 metal ores/metal scrap; $32 \mathrm{coal} /$ coke/briquettes; 33 petroleum and products; 34 gas natural/ manufactured; 66 nonmineral manufactures, which includes precious stones like diamonds; 68 nonferrous metals, including silver, copper, and aluminum; and 97 nonmonetary ore, which includes gold.

${ }^{6}$ In Figure 4, 82 countries with per capita resource exports of less than $\$ 50$ are ignored.

${ }^{7}$ These figures are subject to the available data in the World Integrated Trade Solution database. For Botswana, the authorities' mining export data are used.

${ }^{8}$ Employment data come from the 2001 Population and Housing Census.

${ }^{9}$ This challenge has been recognized since the 1960s, and in the early 1980s the diversification efforts were accelerated through the Financial Assistance Policy.

${ }^{10}$ Indeed, growth accounting reveals that Botswana's growth was mainly driven by capital accumulation rather than improvement in total factor productivity and growth in employment (IMF, 1999).
} 
Figure 3. Natural Resource Exports, 1990-2002

(In billions of U.S. dollars)

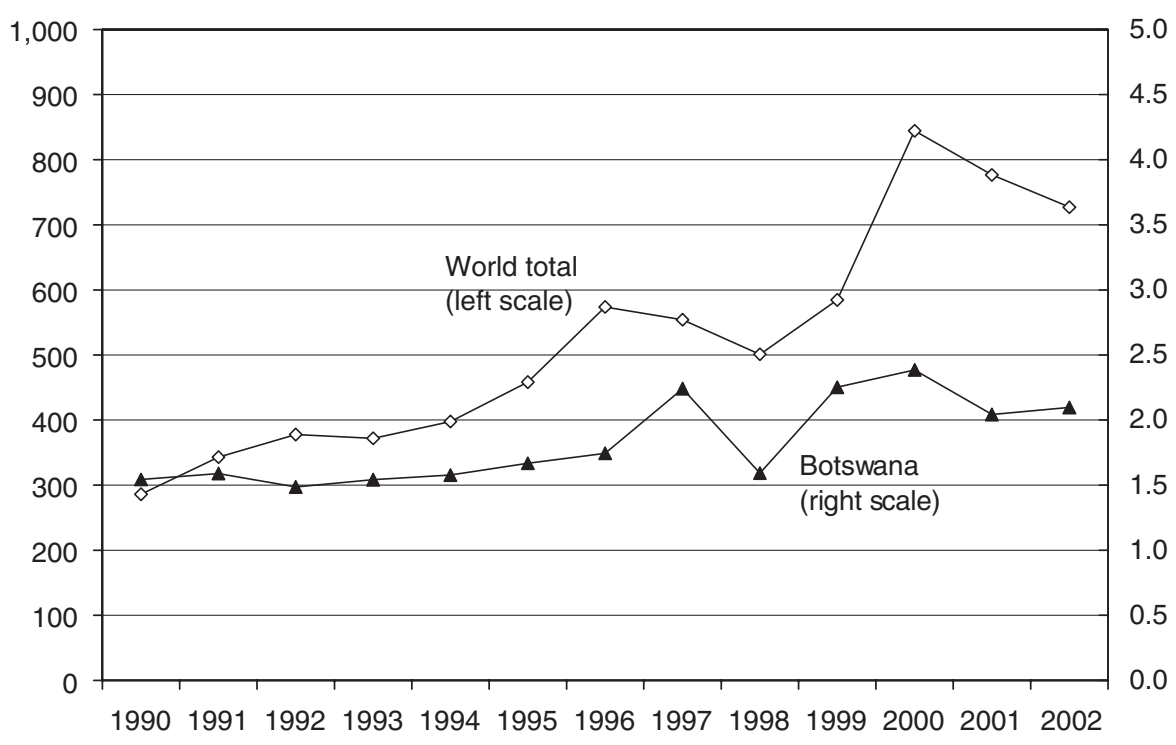

Note: The world figures are the sum of natural resource exports: metal ores/metal scrap (SITC 28), coal/coke briquettes (32), petroleum and products (33), gas natural/manufactured (34), nonmineral manufactures (66), nonferrous metals (68), and nonmonetary ore (97), all from the World Integrated Trade Solution database. The Botswana figures are based on the mineral exports data (i.e., diamonds, copper, and soda ash) available in the Annual Report of the Bank of Botswana.

impact. The empirical analysis that follows takes the landlocked factor into consideration.

Finally, it is debatable whether Botswana has suffered from the typical Dutch disease syndrome. ${ }^{11}$ Between 1998 and 2002, Botswana exported about $\$ 1,200$ of natural resources per capita; at the same time, it suffered a 16 percent deterioration in terms of trade. Yet in the first half of the 1990s, the terms of trade index improved by about 10 percent.

\section{Governance}

In general, good institutions are a key for growth (Acemoglu, Johnson, and Robinson, 2005). It is intuitively apparent that natural resource abundance would be advantageous to any economy whose government has a sound long-term plan for extracting resources and an effective mechanism for

${ }^{11}$ To a certain extent, the recent rapid appreciation of the pula against hard currencies appears to have eroded the external competitiveness of nondiamond exports. However, this effect seems to have been caused by the short-term appreciation of the currency of neighboring South Africa, to which the Botswana currency is mainly pegged. 
Figure 4. Natural Resource Exports per Capita, 1998-2002

(In U.S. dollars; period average)

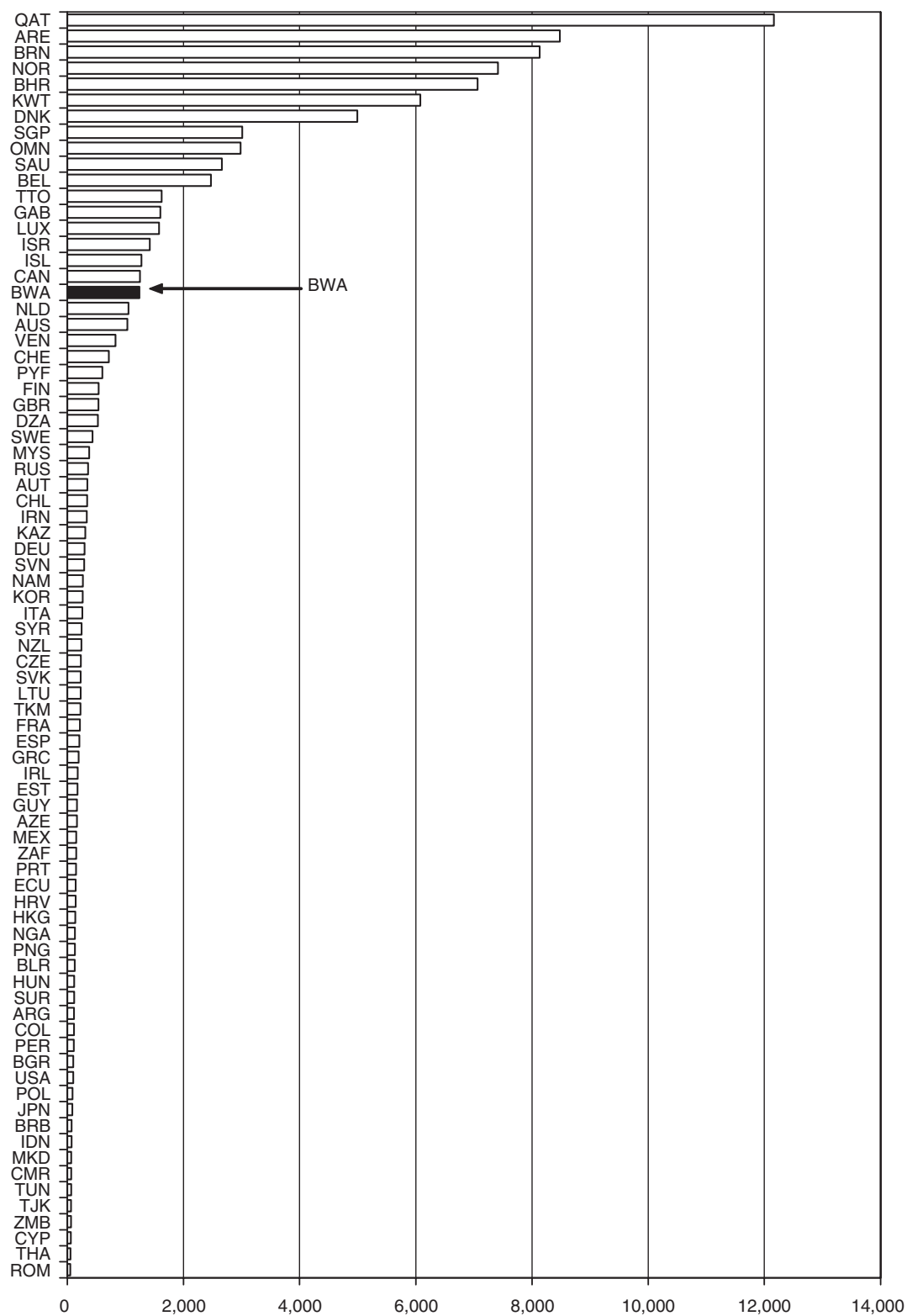

Note: Per capita resource export data are the period average exports divided by population, which cover metal ores/metal scrap (SITC 28), coal/coke briquettes (32), petroleum and products (33), gas natural/manufactured (34), nonmineral manufactures (66), nonferrous metals (68), and nonmonetary ore (97) in the World Integrated Trade Solution database. 
Figure 5. Botswana: Mining Share of GDP, 1980/81-2003/04

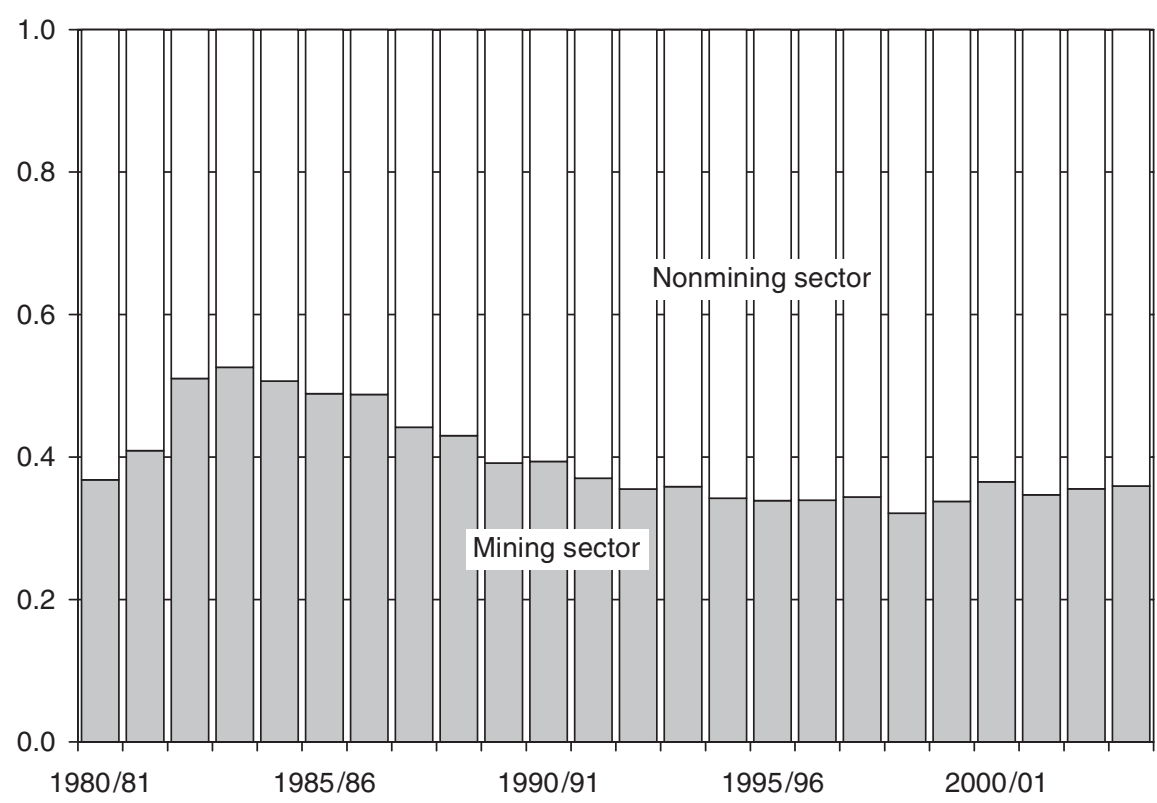

Note: The historical sectoral GDP data for Botswana are available in the Central Bank's Annual Report. The mining sector value added is mostly contributed by diamond production.

spending revenues on the social and economic needs for sustained growth. If governance is poor, resources may be wasted quickly. However, governance may be difficult to define and measure unambiguously. Kaufmann, Kraay, and Mastruzzi (2003) develop the Governance Research Indicator Country Snapshot database, which covers six dimensions of governance: voice and accountability, political stability, government effectiveness, regulatory quality, rule of law, and control of corruption (Table 1). Here, each index is normalized between zero and one. ${ }^{12}$

Four aspects of governance seem to be particularly important for natural resource management. First, voice and accountability, as measured by the political process, civil liberties, and political rights, indicates the ability to discipline those in authority for resource extraction. Without monitoring by the citizens and a process by which those in power may be selected and

\footnotetext{
${ }^{12}$ Kaufmann, Kraay, and Mastruzzi (2003) estimate the degree of governance - defined as country-specific, unobservable characteristics for each governance dimension-using more than a hundred variables that measure perceptions of governance from 25 different data sources, such as those constructed by Freedom House's Freedom in the World, the Economist Intelligence Unit's Country Risk Service, and the World Bank's World Business Environment Survey. The entire series of indices are available at http://info.worldbank.org/governance/ kkz2004.
} 
Figure 6. Botswana: Employment Share by Industry, 2001

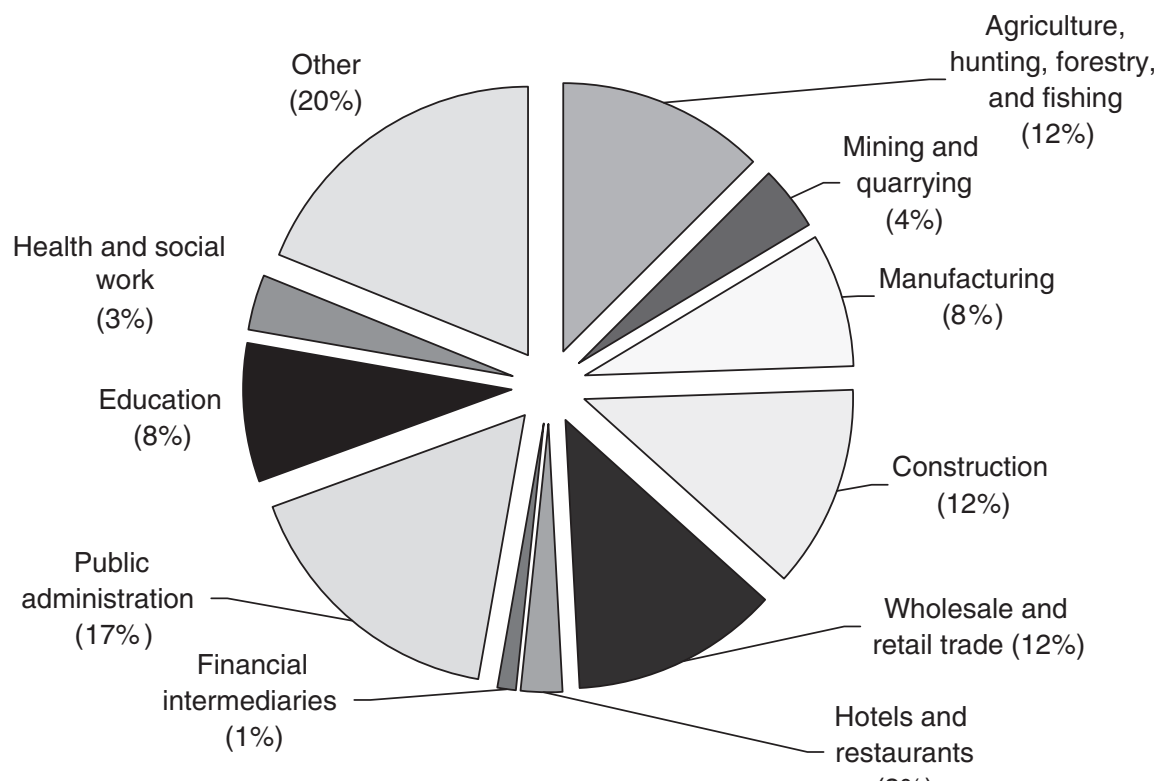

$(3 \%)$

Note: Employment data are based on the 2001 Population and Housing Census published by the Botswana authorities.

replaced, resource rents tend to be dissipated. Second, government effectiveness, measured by the quality of public services and the competence of civil servants, also needs to be high. If the government cannot produce and implement good resource management policies, resource wealth will be overexploited and rapidly exhausted.

Third, because natural resource development must by necessity involve a long-term relationship with private parties, market-unfriendly policies like price controls and excessive regulatory burdens are undesirable. Contracts related to natural resources commonly extend for more than 10 years. ${ }^{13}$ The term for diamond-mining leases in Botswana is 25 years. ${ }^{14}$ Finally, anticorruption policies are essential for fair and transparent distribution of resource benefits.

${ }^{13}$ Mining activity tends to involve long-term contracts at every stage. For example, the U.S. federal government's lease auctions for offshore oil and gas development involve fiveyear contracts with an automatic extension, as long as there is production (Porter, 1995), and the average contract length between coking refiners and aluminum producers is about eight years (Goldberg and Erickson, 1987). Natural gas is usually traded under extended contracts averaging 15 to 20 years (Masten and Crocker, 1985).

${ }^{14}$ The contract between the government of Botswana and Debswana was renewed in September 2004. 
Atsushi limi

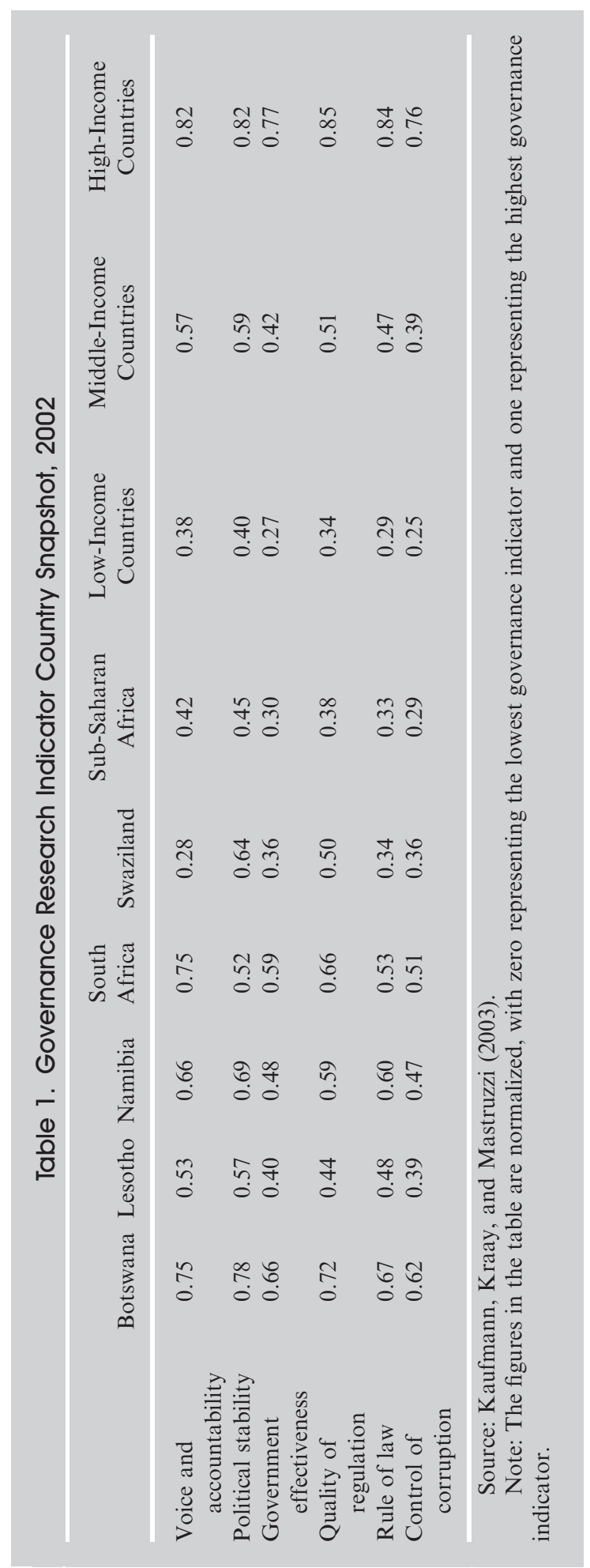


In the case of Botswana, the country seems to have succeeded in establishing sound institutions and good governance (Table 1). Acemoglu, Johnson, and Robinson (2002) point out that Botswana's good institutions, particularly in the private property area, have stemmed from its precolonial political institutions, limited British colonialism, strong political leadership since independence, and the elite's motivation to reinforce institutions.

Notably, their analysis is based on a case study approach. ${ }^{15}$ By focusing on the political structure, particularly the constraints on political elites to avoid distortionary economic policies, they examine why such institutions materialized. By contrast, the current paper concentrates on the growth impact of given institutions in the empirical growth regression framework.

Regardless of the approaches adopted, in fact, the country has done well in the four aspects of governance mentioned above. First, Botswana has a transparent political process; international observers praised as free and fair the 2004 national election, the first conducted under the Southern African Development Community guidelines for democratic elections. Second, Botswana's fiscal system is very sound; use of mineral revenues has followed an implicit self-disciplinary rule, the Sustainable Budget Index (SBI), under which any mineral revenue is supposed to finance "investment expenditure," defined as development expenditure and recurrent spending on education and health. Other recurrent spending is funded from nonmineral revenues. In addition, there is a government asset fund, the Pula Fund, where financial assets are invested only on a long-term basis in a transparent and accountable manner. Although the first rule has been broadly followed for decades, there has been some minor departure in recent years (Figure 7). Violation of the rule tends to have been accompanied by a large fiscal deficit, as in 2001/02 and 2002/03.

Third, the quality of Botswana's regulation is generally acceptable. For instance, the Botswana Telecommunications Authority (BTA) established in 1996 has been praised as one of the first independent regulatory authorities in Africa (ITU, 2001). ${ }^{16}$ However, there may remain some regulations that

\footnotetext{
${ }^{15}$ They have rejected their regression analysis because Botswana looks like a statistical outlier in their sample.

${ }^{16}$ The 1996 Telecommunications Act provided the legislative foundation for BTA to have full and exclusive responsibility for licensing telecommunications and broadcasting operators, settling disputes among operators, approving tariffs, promoting and monitoring free and fair competition, allocating spectrum rights, approving terminal equipment, and protecting consumers. However, it has recently suffered a setback in regulatory independence from political pressures. A 2004 amendment of the telecommunications bill was meant to bring the BTA under the control of the Ministry of Work, Transport and Communication (MWTC), which was then divided into Ministry of Communications, Science and Technology (MCST), and Ministry of Works and Transport. It requires the BTA to submit its operation plans and give the MCST its powers to set regulations and licensing fees.
} 
Figure 7. Botswana: Mineral Revenue and Investment Expenditure, 1985/86-2003/04 (Millions of pula)

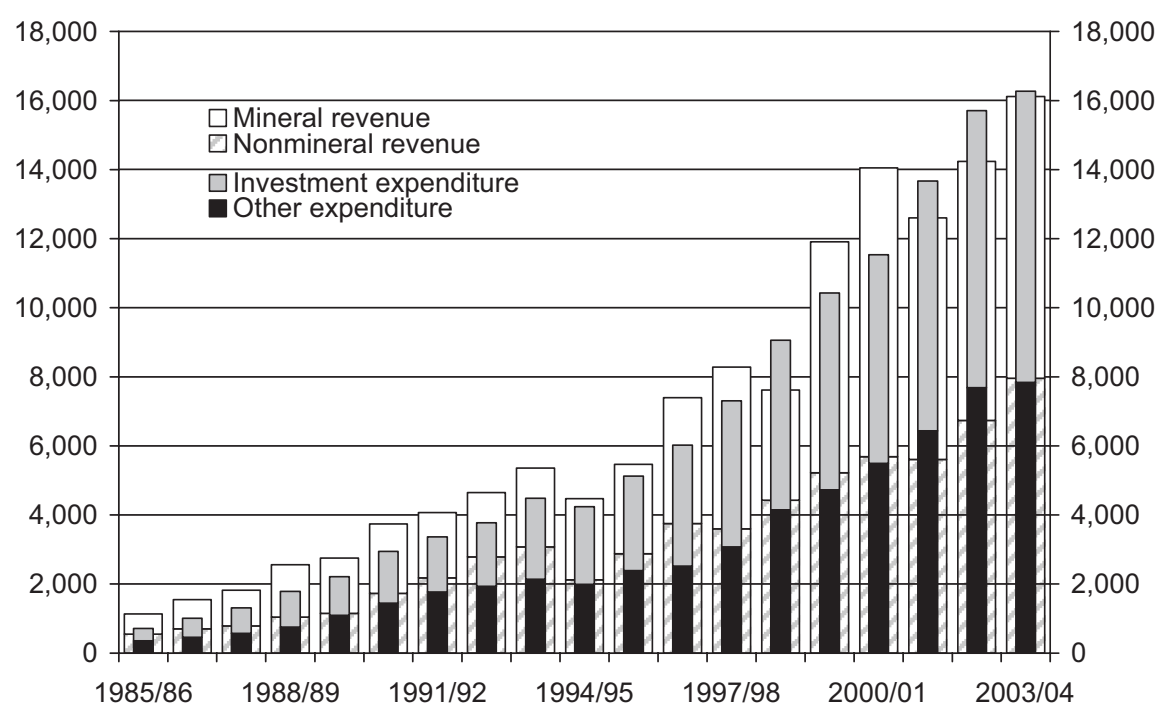

Note: The historical fiscal data come from a series of annual reports of Bank of Botswana and IMF Country Report No. 06/66 for the latest figures. The nonmineral revenue consists of tax and nontax revenues other than mineral revenue. Investment expenditure is defined as the sum of development (capital) expenditure and recurrent costs for education and health. Recurrent expenditures in the other sectors comprise "other expenditure."

restrict labor mobility and business opportunities. ${ }^{17}$ In the mining sector, the government of Botswana retains 50 percent of the shares in Debswana, the largest diamond firm in the country, and the Ministry of Minerals, Energy and Water Resources has direct responsibility generally for natural resource regulation and management. Finally, corruption in the public sector is not a serious problem in the country. The budgetary and procurement process is relatively transparent. An independent anticorruption authority established in 1994, the Directorate of Corruption and Economic Crime, has the authority to report corruption cases directly to the president. The constitution also makes the attorney general independent of the government and politicians. This sound anticorruption framework is considered to be conducive to proper resource management in Botswana.

\footnotetext{
${ }^{17}$ One of the burdens for foreign companies starting businesses in Botswana is the restriction on employing foreign labor. Companies that hire foreign experts, particularly lessskilled labor, must prove that the expertise cannot be found in the domestic market, and then localize the skills through internal job training programs afterward. The World Bank's survey also indicates that Botswana's administrative process for registering new businesses is very slow by regional and global standards (World Bank, 2004).
} 
But do these governance factors really affect growth and natural resources? As shown in Figure 8, where the anticorruption indicator is taken as an example, the recent growth rate cannot simply be explained by natural resource abundance, even though there is a slight positive correlation between growth and governance, and resource abundance is positively associated with governance.

Economic growth has not been high in some other resource-abundant countries, such as Indonesia, Venezuela, and Nigeria, partly because of inadequate governance. On the other hand, resource-scarce countries have sometimes attained relatively high economic growth, like the Maldives, which has good governance. There are other anomalies: although Malaysia, for instance, has abundant natural resources and good governance, it has low economic growth for this sample period. Albania is a resource-scarce country with poor governance that has somehow achieved marked growth. Therefore, not only governance but also other macroeconomic elements must affect the relationship between natural resource wealth and economic growth.

\section{Methodology}

\section{Regression Models}

To examine the relationship between natural resource wealth, growth, and governance, this paper follows the standard empirical growth literature (for example, Mankiw, Romer, and Weil, 1992; Barro and Sala-i-Martin, 1995; and Barro, 1997) and uses the following linear growth regression model: ${ }^{18}$

$$
\begin{aligned}
g= & \alpha_{0}+\alpha_{1} M I N+\alpha_{2} \theta+\alpha_{3} M I N \times \theta+\alpha_{4} n+\alpha_{5} \tau \\
& +\alpha_{6} T R A+X^{\prime} \alpha_{7}+\varepsilon,
\end{aligned}
$$

where $g$ is the real per capita growth rate, $M I N$ is a proxy of mineral resource abundance, ${ }^{19} \theta$ is one of the governance indicators, $n$ is population growth, and $\tau$ is the average tax rate. $T R A$ is a proxy representing the degree of trade openness, and $X$ includes exogenous variables to control for heterogeneity across countries. ${ }^{20}$ The equation has an interaction term between resource abundance and governance that allows us to address the primary question

\footnotetext{
${ }^{18}$ Farzin (1999) has an endogenous growth model with exhaustible natural resources.

${ }^{19}$ The estimation equation is based on the conditional convergence hypothesis, in which per capita growth is conditional on initial income and other variables, including natural resource abundance in this case. In earlier empirical work, natural resource richness is usually measured by resource exports owing to data availability (for example, Sachs and Warner, 1995; and Papyrakis and Gerlagh, 2004). This treatment generates an apparent concern about endogeneity that GDP growth is regressed over exports. In fact, diamond exports contribute to approximately 35 to 40 percent of GDP in Botswana. However, this problem must be solved by employing instrumental variables (see the following section).

${ }^{20}$ According to the Ramsay RESET test, the hypothesis that this model has no crucial omitted variables cannot be rejected. The $F$ statistics are estimated at 0.29 to 0.88 , depending on which governance indicator is selected.
} 
Figure 8. Natural Resources, Growth, and Anticorruption Policies, 1998-2002
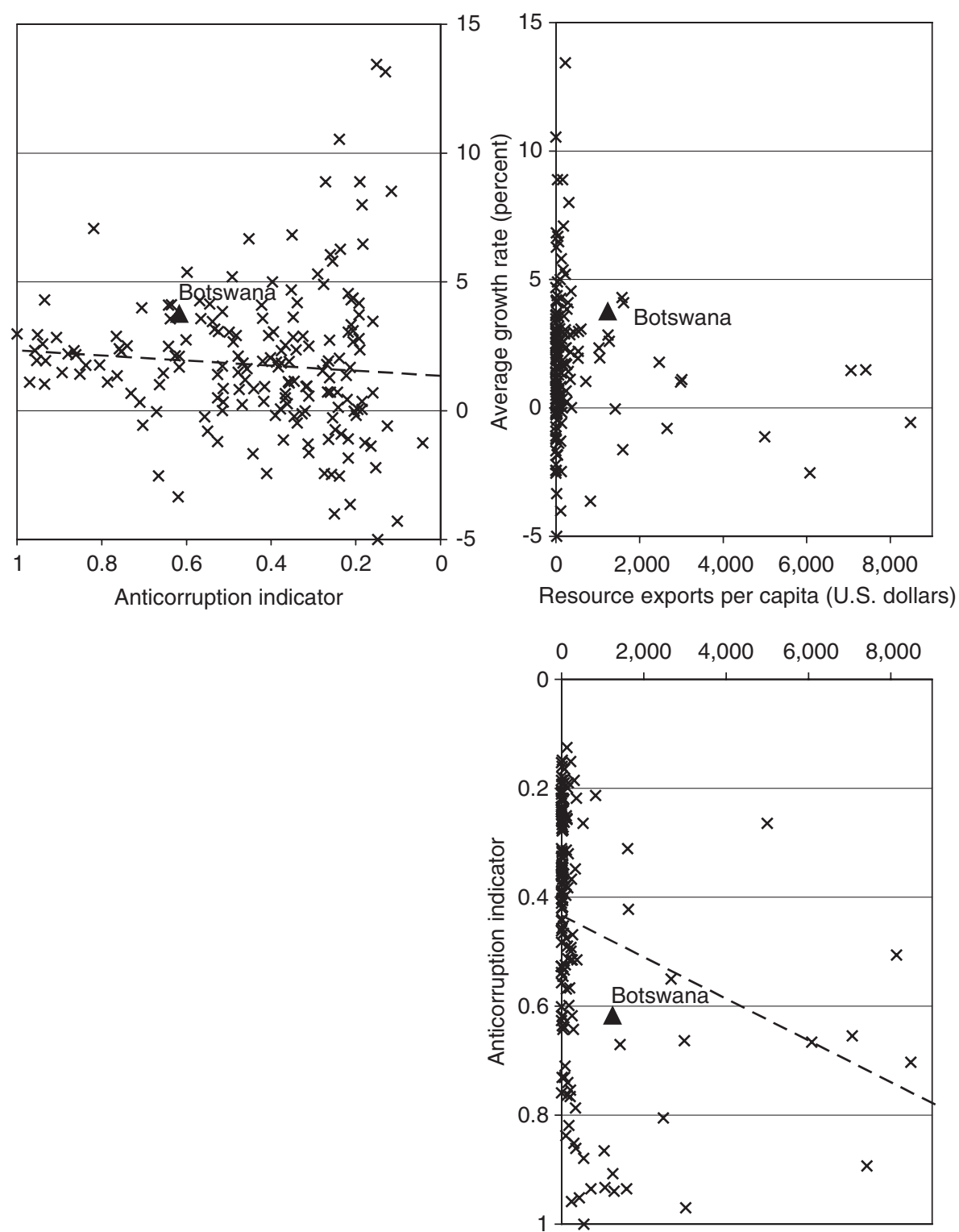

Note: The individual pictures plot the bivariate relationship between per capita GDP growth, normalized anticorruption index, and natural resource exports per capita. The broken lines represent a statistically significant linear association between two variables. Per capita GDP growth rates come from World Bank, World Development Indicators and the anticorruption index is based on Kaufmann, Kraay, and Mastruzzi (2003). The resource exports are divided by population and come from the World Integrated Trade Solution database (see also Figure 1). 
motivating this paper: whether and how natural resource richness and governance factors influence economic growth.

Of particular note: the average tax rate is supposed to capture the conventional effect of government intervention in the economy (for example, Romer, 1996). If the tax rate is significantly high, economic growth is likely to stagnate. On the other hand, $T R A$ is supposed to represent generally expected positive impacts of trade liberalization on growth.

When particular attention is paid to the Dutch disease syndrome, another equation can be estimated that incorporates the indirect terms of trade effect:

$$
\begin{aligned}
g= & \beta_{0}+\beta_{1} M I N+\beta_{2} \theta+\beta_{3} M I N \times \theta+\beta_{4} n+\beta_{5} \tau \\
& +\beta_{6} T R A+X^{\prime} \beta_{7}+\beta_{8} \hat{\mu}+\varepsilon,
\end{aligned}
$$

$\hat{\mu}$ is obtained as a residual from the following transmission channel equation:

$$
T O T=\gamma_{0}+\gamma_{1} M I N+\mu,
$$

where TOT denotes a change in terms of trade. ${ }^{21}$

\section{Econometric Issues}

The most important econometric issue in estimating Equations (1) through (3) with aggregated cross-country data is how to deal with biases caused by measurement errors and endogeneity. In this analysis, growth is affected by governance and natural resource extraction; at the same time, resource exploitation and governance are likely to be determined systematically by the stage of economic development. Consequently, the independent variables may be contemporaneously correlated with the error term. To solve this problem, the analysis uses five-year lagged values of the independent variables as instrumental variables, because there is usually no correlation between the disturbance and the lagged values. ${ }^{22}$ The original variables for the period from 1998 to 2002 are instrumented by the lagged equivalents from 1992 to 1996.

Although taking lagged variables may be one of the traditional instrumentation strategies in this area, one might be concerned about the validity of these instruments. The validity of lagged institutions as instruments depends on the assumption that the past institutions are somewhat relevant to the current ones but have no direct effect on current economic performance. Table 2 shows simple correlations between the current and lagged governance indices. They are strongly correlated with one another. More formally, in the first-stage regressions those lagged variables have considerable explanatory power for current institutions. On the other

\footnotetext{
${ }^{21}$ For the derivation of the growth equation with an indirect resource effect, see Papyrakis and Gerlagh (2004).

${ }^{22}$ In fact, the lagged values are considered valid instruments. The correlation of the residuals in the growth regressions at two periods is not crucially high. The estimated correlations are from -0.035 to 0.066 , depending upon the specifications.
} 
Table 2. Instrumental Validity of Lagged Governance

$\begin{array}{lccc} & \begin{array}{c}\text { Correlation between } \\ \text { Current and Lagged } \\ \text { Governance }\end{array} & \begin{array}{c}R \text {-squared in the } \\ \text { First-Stage Regression } \\ \text { on Each Governance } \\ \text { Index }\end{array} & \begin{array}{c}\text { Correlation between } \\ \text { Current Growth and } \\ \text { Lagged Governance }\end{array} \\ \begin{array}{l}\text { Voice and } \\ \text { accountability }\end{array} & 0.934 & 0.914 & 0.133 \\ \begin{array}{l}\text { Political stability } \\ \text { Government } \\ \text { effectiveness }\end{array} & 0.821 & 0.775 & 0.172 \\ \begin{array}{l}\text { Regulatory quality } \\ \text { Rule of law }\end{array} & 0.951 & 0.940 & 0.108 \\ \begin{array}{l}\text { Control of } \\ \text { corruption }\end{array} & 0.872 & 0.896 & 0.038 \\ \end{array}$

Note: The first column indicates a bivariate correlation between the 1996 and 2002 indices for each governance element from Kaufmann, Kraay, and Mastruzzi (2003). The last column is similarly a simple correlation between the 1996 governance index and the average growth rate of per capita GDP for 1998-2002. To indicate the explanatory power of lagged to current governance, the second column represents the $R$-squared in the first-stage regression, where each governance indicator is regressed on various exogenous and instrumental variables shown in Table 3 (see the following analysis). Each row here corresponds to each column in Table 3.

hand, the current growth rate is only slightly correlated with lagged institutions (the last column). In addition, it has been found that there is little correlation between the estimated residual and lagged governance. Therefore, lagged institutions can be expected to mitigate our potential endogenous bias, even though it is never eliminated completely. Note that the 1996 figures are the oldest data available.

In addition, when using colonial experiences and cultural factors as instruments, it has been found that the main estimation results being reported in the following sections would be broadly unchanged, though the coefficients in question tend to be less significant with a $p$-value ranging from 0.161 to $0.286{ }^{23}$ The underlying rationale of these alternative instruments is that European suzerains introduced good institutions and culture to their colonies (Acemoglu, Johnson, and Robinson, 2005). Current institutions are instrumented by the mortality rates faced by the colonial settlers, and it is shown that institutions matter (Acemoglu, Johnson, and Robinson, 2001).

Another important issue is how to treat potential outliers in data. As shown in Figure 4, the natural resource distribution is very skewed, so that

${ }^{23}$ Instead of lagged governance indices, I used (a) colonial experiences in 1914 (French, Dutch, Turkish, and English colonies), (b) languages (Arabic, French, German, and Spanish), and (3) religions (Buddhism and Hinduism) as a set of instruments for institutions. Other possible dummy variables are omitted due to multicollinearity. 
resource-rich countries, though a main target of this research, tend to lie substantially outside the likely population. According to the conventional statistical test where outliers are defined observations lying outside the level of two per million for a normal population, the acceptable maximum of mineral exports per capita is estimated at $\$ 1,312$. In the current sample, eight of 89 countries may be viewed as severe outliers. Fortunately, however, it has been found that the exclusion of outliers in terms of natural resource endowment has little effect on the estimation results. Therefore, no observation is excluded from the analysis. ${ }^{24}$

\section{Empirical Results}

\section{Basic Regression Results}

The appendix describes the sample data. Six instrumental variable (IV) regressions are performed with data that include high-income countries. The results are shown in Table 3. There are several interesting findings:

First, the coefficients of natural resources per capita tend to be negative when the interactive term of resource endowment and governance is included. For several models, those coefficients are statistically significant. ${ }^{25}$ This evidence supports the resource curse hypothesis found in earlier studies.

Second, the effects of governance are not statistically significant. This is not necessarily contradictory to certain expectations of the international donor community. It means that governance is less likely to matter for growth over the very short horizon of a few years, as modeled in this paper. More convincing evidence might be derived from very long-term regressions.

Third, the interaction terms between resource abundance and governance have significant positive coefficients, meaning that if the country has good governance, particularly in terms of voice and accountability, government effectiveness, the quality of regulation, and anticorruption policies, resource wealth is conducive to economic development. Because this result is statistically robust, it can be concluded that resource abundance does not guarantee faster growth, but with proper government resource management, growth can be generated from resource richness. In other words, the absence of the positive relationship between resource abundance and economic development is attributable to a lack of good governance.

As illustrated in Figure 9, when the other conditions are controlled, Botswana seems to have taken advantage of its relatively good governance institutions to maximize the catalytic effect and transform resource abundance into growth. The figure shows the relationship between unexplained growth and the interaction term between resource exports and the governance indicator.

\footnotetext{
${ }^{24}$ In terms of growth rates, there is no severe outlier in the sample.

${ }^{25}$ Without the interaction term, neither resource abundance nor governance tends to be significant.
} 


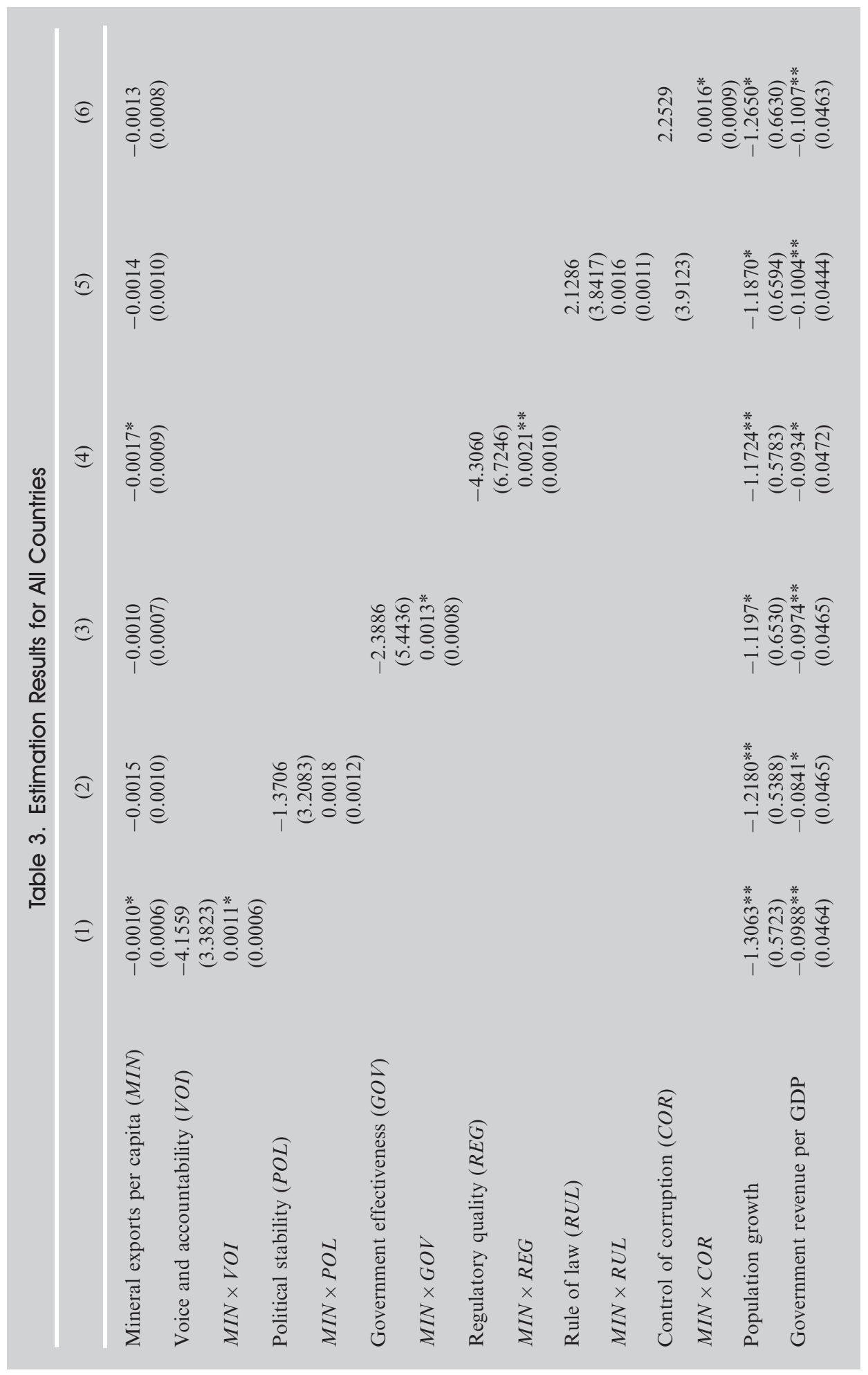




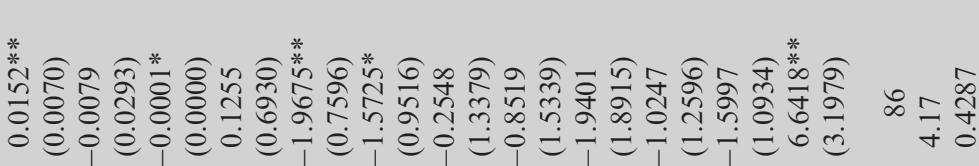

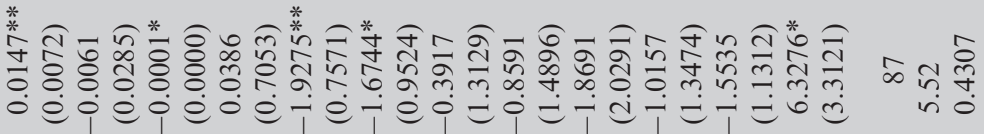

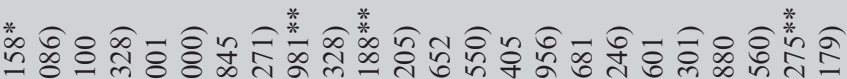

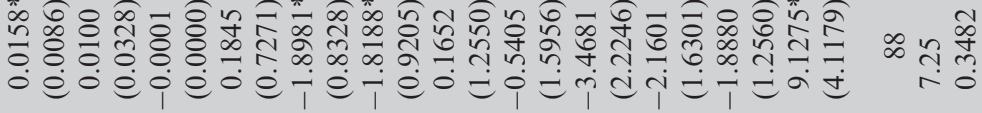

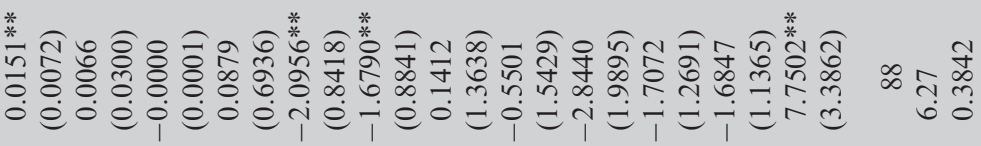

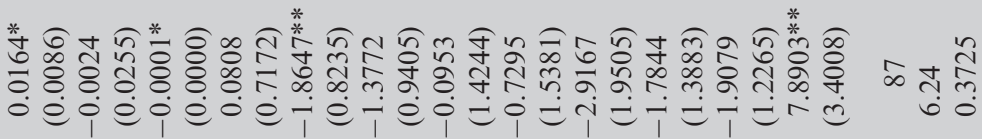

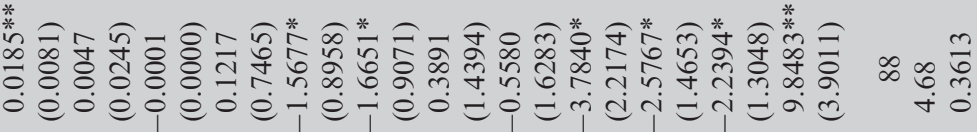

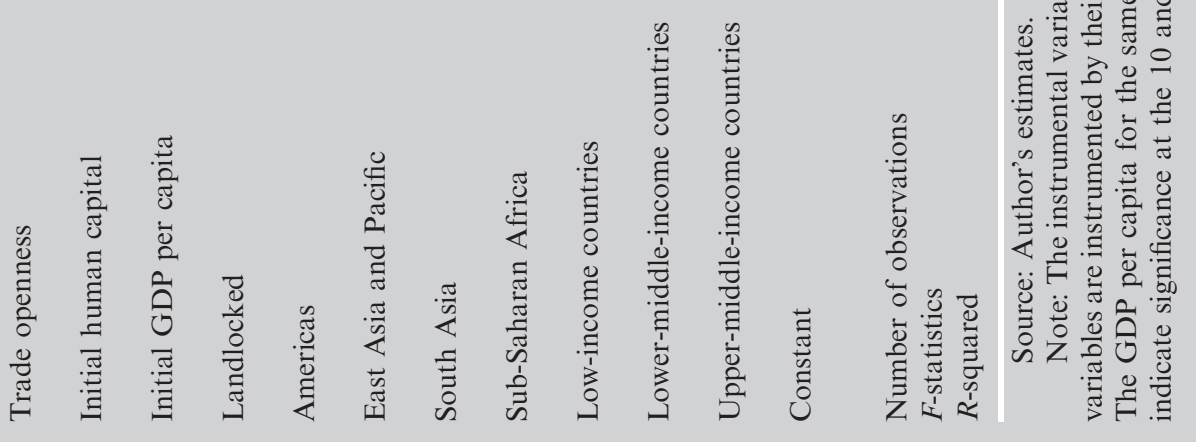


Figure 9. Interactive Effect of Resource Abundance and Governance on Growth
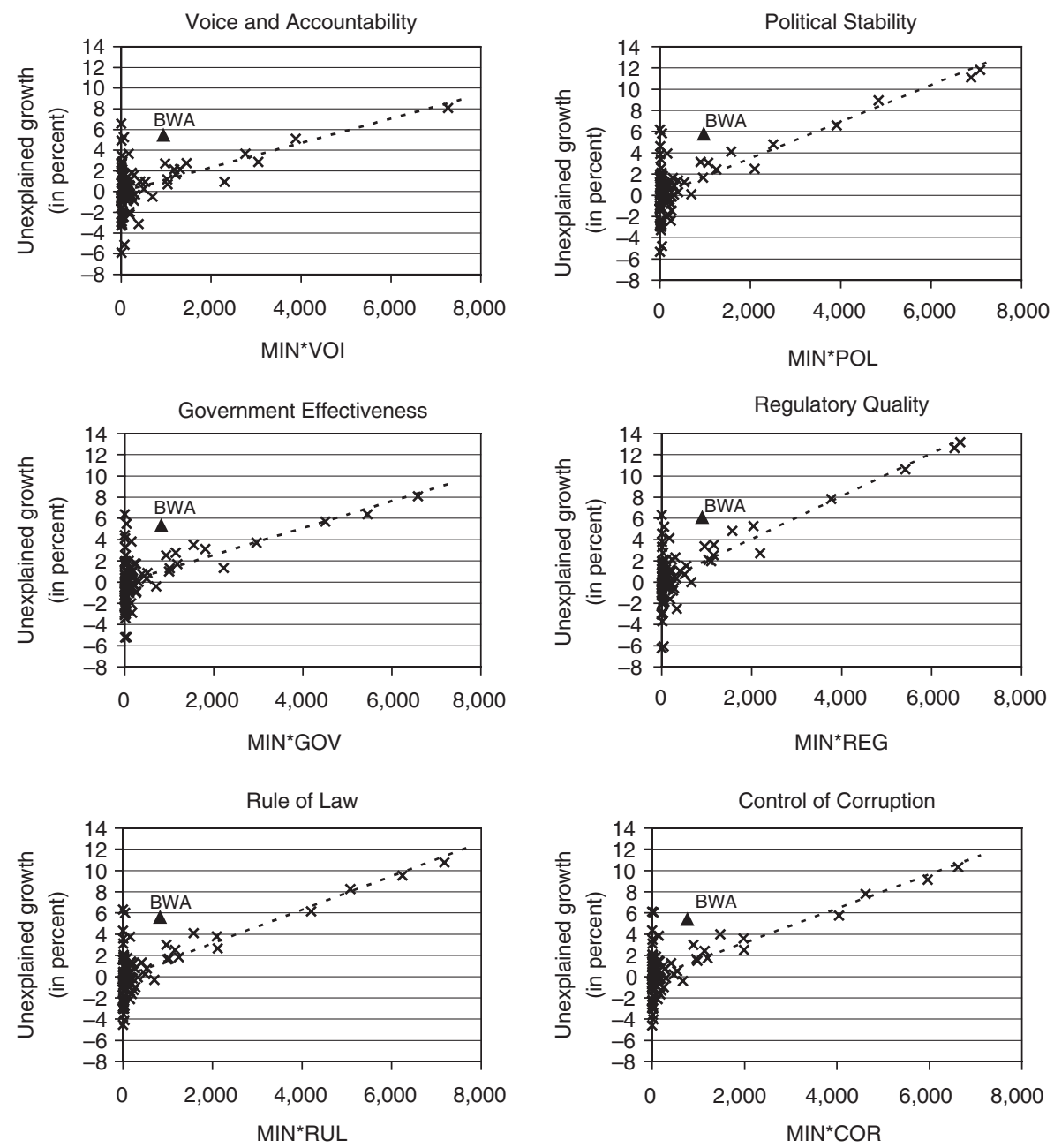

Note: Each figure depicts the relationship between an interactive term of the governance index and per capita resource exports and an unexplained part of the growth rate by variables other than the interactive term. For each column model in Table 3, the unexplained growth is calculated as the actual growth rate minus the predicted value based on all the individual independent variables except the interactive term, and their estimated coefficients.

As for other explanatory variables, an increase in the average tax rate has a negative impact on growth, as earlier growth studies found (see, for example, Barro, 1990; and Davoodi and Zou, 1998). This supports the conventional theoretical prediction that an increase in public purchases slows economic development.

The coefficients of trade openness are significant and positive. This evidence supports the conventional argument promoting trade liberalization. Contrary to expectations, on the other hand, the coefficients of the 
Table 4. Indirect Transmission Channels

$\begin{array}{lcc} & \text { All of Sample } & \text { Developing Countries Only } \\ \text { Mineral exports per capita }(M I N) & 0.0085^{* * *} & 0.0246 * * * \\ & (0.0022) & (0.0067) \\ \text { Constant } & -1.6812 & -1.9993 \\ & (1.9619) & (2.2126) \\ \text { Number of observations } & 86 & 58 \\ F \text {-statistics } & 14.20 & 13.56 \\ R \text {-squared } & 0.3052 & 0.2782\end{array}$

Source: Author's estimates.

Note: To see the possible indirect growth impact of massive natural resources through improved terms of trade, the ordinary least squares estimation is performed where the dependent variable is terms of trade and only the independent variable is natural resource exports per capita. The White-heteroscedasticity-consistent standard errors are shown in parentheses. $* * *$ indicates significance at the 1 percent level.

landlocked dummy variable are positive, though not significant. Statistically, the landlocked effect seems to be absorbed by the income group dummy variables, implying that slow growth in landlocked economies is attributable to more general economic and social disadvantages shared by low-income countries rather than to geographical constraints. The population growth coefficient is negative and significant in a statistical sense, consistent with earlier studies. Some systematic differences among regions are also observed.

\section{The Dutch Disease Hypothesis}

Table 4 shows the estimation results of the indirect effect of resource abundance on terms of trade. Paradoxically, resource richness improves terms of trade. ${ }^{26}$ With this indirect effect incorporated, the results of the IV regressions, presented in Table 5, are quite similar to those in Table 3. The indirect effect of terms of trade retrieved from the $M I N$ coefficients in Table 4 and the $\hat{\mu}$ coefficients in Table 4 is very small. This can be interpreted to mean that for this period the Dutch disease syndrome has little effect on the linkage between natural resource abundance and economic development.

\section{Robustness}

One remaining econometric concern is that developing countries might not share the same growth structure as developed countries. Table 6 presents the estimation results for developing countries only. Although the statistical

\footnotetext{
${ }^{26}$ This improvement may reflect the fact that the relationship between resource abundance and terms of trade is self-evident in the sense that the resource measurement used here is defined in value rather than quantity terms. Higher international commodity prices are associated with greater natural resource endowments as well as higher export prices.
} 
Table 5. Estimation Results, Including Indirect Terms of Trade Effect

\begin{tabular}{|c|c|c|c|c|c|c|}
\hline & (1) & (2) & (3) & (4) & (5) & (6) \\
\hline $\begin{array}{l}\text { Mineral exports per } \\
\text { capita }(M I N)\end{array}$ & $\begin{array}{l}-0.0010 \\
(0.0006)^{*}\end{array}$ & $\begin{array}{r}-0.0016 \\
(0.0010)\end{array}$ & $\begin{array}{r}-0.0012 \\
(0.0007)\end{array}$ & $\begin{array}{r}-0.0021^{*} \\
(0.0011)\end{array}$ & $\begin{array}{r}-0.0018^{*} \\
(0.0010)\end{array}$ & $\begin{array}{r}-0.0017^{*} \\
(0.0009)\end{array}$ \\
\hline $\begin{array}{l}\text { Voice and } \\
\text { accountability } \\
(V O I)\end{array}$ & $\begin{array}{c}-3.9395 \\
(3.5294)\end{array}$ & & & & & \\
\hline$M I N \times V O I$ & $\begin{array}{c}0.0012 * \\
(0.0007)\end{array}$ & & & & & \\
\hline $\begin{array}{l}\text { Political stability } \\
\qquad(P O L)\end{array}$ & & $\begin{array}{c}-1.1234 \\
(3.2406)\end{array}$ & & & & \\
\hline$M I N \times P O L$ & & $\begin{array}{r}0.0019^{*} \\
(0.0012)\end{array}$ & & & & \\
\hline $\begin{array}{l}\text { Government } \\
\text { effectiveness } \\
(G O V)\end{array}$ & & & $\begin{array}{c}-1.3421 \\
(5.6547)\end{array}$ & & & \\
\hline$M I N \times G O V$ & & & $\begin{array}{l}0.0015 * \\
(0.0009)\end{array}$ & & & \\
\hline $\begin{array}{l}\text { Regulatory quality } \\
\qquad(R E G)\end{array}$ & & & & $\begin{array}{r}-3.9673 \\
(6.7780)\end{array}$ & & \\
\hline$M I N \times R E G$ & & & & $\begin{array}{c}0.0026^{*} \\
(0.0014)\end{array}$ & & \\
\hline Rule of law $(R U L)$ & & & & & $\begin{array}{c}3.4048 \\
(4.2299)\end{array}$ & \\
\hline$M I N \times R U L$ & & & & & $\begin{array}{l}0.0022 * \\
(0.0012)\end{array}$ & \\
\hline $\begin{array}{l}\text { Control of } \\
\text { corruption } \\
(C O R)\end{array}$ & & & & & & $\begin{array}{c}2.8575 \\
(3.7133)\end{array}$ \\
\hline$M I N \times C O R$ & & & & & & $\begin{array}{l}0.0021 * \\
(0.0012)\end{array}$ \\
\hline$\hat{\mu}$ & $\begin{array}{c}0.0011 \\
(0.0235)\end{array}$ & $\begin{array}{c}0.0069 \\
(0.0231)\end{array}$ & $\begin{array}{c}0.0086 \\
(0.0246)\end{array}$ & $\begin{array}{c}0.0110 \\
(0.0272)\end{array}$ & $\begin{array}{c}0.0141 \\
(0.0235)\end{array}$ & $\begin{array}{c}0.0110 \\
(0.0225)\end{array}$ \\
\hline Population growth & $\begin{array}{c}-1.2843 * * \\
(0.5385)\end{array}$ & $\begin{array}{c}-1.1899 * * \\
(0.5005)\end{array}$ & $\begin{array}{c}-1.1085^{*} \\
(0.5886)\end{array}$ & $\begin{array}{c}-1.1229 * * \\
(0.5119)\end{array}$ & $\begin{array}{c}-1.1430 * \\
(0.5896)\end{array}$ & $\begin{array}{c}-1.2300 * * \\
(0.5742)\end{array}$ \\
\hline $\begin{array}{l}\text { Government } \\
\text { revenue per GDP }\end{array}$ & $\begin{array}{c}-0.1004 * * \\
(0.0450)\end{array}$ & $\begin{array}{r}-0.0822 * \\
(0.0445)\end{array}$ & $\begin{array}{c}-0.0964 * * \\
(0.0461)\end{array}$ & $\begin{array}{r}-0.0898^{*} \\
(0.0436)\end{array}$ & $\begin{array}{c}-0.1025 * * \\
(0.0443)\end{array}$ & $\begin{array}{c}-0.1020 * * \\
(0.0459)\end{array}$ \\
\hline Trade openness & $\begin{array}{c}0.0161 \\
(0.0109)\end{array}$ & $\begin{array}{c}0.0133 \\
(0.0109)\end{array}$ & $\begin{array}{c}0.0116 \\
(0.0094)\end{array}$ & $\begin{array}{c}0.0123 \\
(0.0104)\end{array}$ & $\begin{array}{c}0.0112 \\
(0.0090)\end{array}$ & $\begin{array}{c}0.0121 \\
(0.0090)\end{array}$ \\
\hline $\begin{array}{l}\text { Initial human } \\
\text { capital }\end{array}$ & $\begin{array}{c}0.0072 \\
(0.0238)\end{array}$ & $\begin{array}{c}0.0017 \\
(0.0277)\end{array}$ & $\begin{array}{c}0.0088 \\
(0.0306)\end{array}$ & $\begin{array}{c}0.0138 \\
(0.0263)\end{array}$ & $\begin{array}{c}-0.0020 \\
(0.0257)\end{array}$ & $\begin{array}{c}-0.0032 \\
(0.0229)\end{array}$ \\
\hline $\begin{array}{l}\text { Initial GDP per } \\
\text { capita }\end{array}$ & $\begin{array}{c}-0.0001 * * \\
(0.0000)\end{array}$ & $\begin{array}{c}-0.0001 * * \\
(0.0000)\end{array}$ & $\begin{array}{r}-0.0001 \\
(0.0001)\end{array}$ & $\begin{array}{c}-0.0001 * * \\
(0.0000)\end{array}$ & $\begin{array}{l}-0.0001 * * * \\
(0.0000)\end{array}$ & $\begin{array}{c}-0.0001 * * * \\
(0.0000)\end{array}$ \\
\hline Landlocked & $\begin{array}{c}0.2485 \\
(0.7984)\end{array}$ & $\begin{array}{c}0.2671 \\
(0.7841)\end{array}$ & $\begin{array}{c}0.3119 \\
(0.7484)\end{array}$ & $\begin{array}{c}0.4080 \\
(0.8049)\end{array}$ & $\begin{array}{c}0.2611 \\
(0.7659)\end{array}$ & $\begin{array}{c}0.3576 \\
(0.7651)\end{array}$ \\
\hline Americas & $\begin{array}{c}-1.6464 * \\
(0.9198)\end{array}$ & $\begin{array}{c}-1.8355^{* *} \\
(0.8378)\end{array}$ & $\begin{array}{c}-2.0263 * * \\
(0.8396)\end{array}$ & $\begin{array}{c}-1.8738 * * \\
(0.8468)\end{array}$ & $\begin{array}{c}-1.8126 * * \\
(0.7524)\end{array}$ & $\begin{array}{c}-1.9357 * * \\
(0.7450)\end{array}$ \\
\hline $\begin{array}{l}\text { East Asia and } \\
\text { Pacific }\end{array}$ & $\begin{array}{r}-1.6597^{*} \\
(0.8768)\end{array}$ & $\begin{array}{c}-1.3118 \\
(0.8964)\end{array}$ & $\begin{array}{c}-1.6222 * \\
(0.8301)\end{array}$ & $\begin{array}{r}-1.6799 * \\
(0.8889)\end{array}$ & $\begin{array}{r}-1.6598^{*} \\
(0.9010)\end{array}$ & $\begin{array}{c}-1.5257 * \\
(0.8910)\end{array}$ \\
\hline South Asia & $\begin{array}{c}0.3111 \\
(1.5023)\end{array}$ & $\begin{array}{c}0.0010 \\
(1.5220)\end{array}$ & $\begin{array}{c}0.1140 \\
(1.4070)\end{array}$ & $\begin{array}{c}0.2506 \\
(1.3614)\end{array}$ & $\begin{array}{r}-0.4323 \\
(1.3295)\end{array}$ & $\begin{array}{r}-0.2181 \\
(1.3693)\end{array}$ \\
\hline
\end{tabular}


Table 5 (concluded)

\begin{tabular}{lcccccc} 
& $(1)$ & $(2)$ & $(3)$ & $(4)$ & $(5)$ & $(6)$ \\
\hline Sub-Saharan & -0.5344 & -0.5126 & -0.3763 & -0.2756 & -0.5185 & -0.5938 \\
$\quad$ Africa & $(1.7206)$ & $(1.6849)$ & $(1.6166)$ & $(1.7035)$ & $(1.5721)$ & $(1.5746)$ \\
Low-income & $-4.0601^{*}$ & -3.2876 & -3.1483 & $-3.9457 *$ & -2.2063 & -2.4381 \\
$\quad$ countries & $(2.4521)$ & $(2.0493)$ & $(2.1269)$ & $(2.3864)$ & $(2.1209)$ & $(2.0413)$ \\
Lower-middle- & $-2.8217^{*}$ & -2.0951 & -1.9985 & -2.5319 & -1.3101 & -1.4209 \\
$\quad$ income countries & $(1.4904)$ & $(1.3400)$ & $(1.2342)$ & $(1.6204)$ & $(1.3321)$ & $(1.2224)$ \\
Upper-middle- & $-2.4092^{*}$ & $-2.1939 *$ & -2.0034 & $-2.2124^{*}$ & -1.9352 & $-1.9714^{*}$ \\
$\quad$ income countries & $(1.4351)$ & $(1.2961)$ & $(1.2424)$ & $(1.3078)$ & $(1.1941)$ & $(1.1692)$ \\
Constant & $10.0491^{* *}$ & $7.9376^{* *}$ & $7.6892^{* *}$ & $9.1712^{* *}$ & $6.0418^{* *}$ & $6.7396^{* *}$ \\
& $(3.8623)$ & $(3.1950)$ & $(3.0562)$ & $(3.9762)$ & $(3.0095)$ & $(2.9489)$ \\
Number of & & & & & & 84 \\
$\quad$ observations & 86 & 85 & 86 & 86 & & \\
$F$-statistics & 4.28 & 5.05 & 6.40 & 7.45 & 4.52 & 3.75 \\
$R$-squared & 0.3633 & 0.3811 & 0.4045 & 0.3598 & 0.4509 & 0.4436
\end{tabular}

Source: Author's estimates.

Note: The instrumental variable (IV) estimations are performed where the dependent variable is GDP per capita growth and various relevant macro variables are instrumented by their lagged values. The indirect terms of trade impact, measured by the residual estimated in Table 4 , is also included as one of the independent variables. The White-heteroscedasticityconsistent standard errors are shown in parentheses. $*$, **, and *** indicate significance at the 10,5 , and 1 percent levels, respectively.

significance of some explanatory variables is changed, the main results hold. Although the coefficients of natural resource abundance continue to be negative, only two governance indicators that interact with the resource variable retain significant coefficients: regulatory quality and control of corruption. Thus, in developing countries, sound government regulation and anticorruption policies are of particular importance for natural resource management.

More formally, at the 1 percent significance level, the standard structural test tends to accept the hypothesis that all the coefficients except those associated with regional and income group dummy variables are the same for both high-income and developing countries. The Wald statistics are estimated at 1.10 to 3.08 , depending on the governance indicators used. ${ }^{27}$

In Table 6, the strong negative coefficients associated with initial GDP per capita imply that there is a conditional convergence in national incomes.

\footnotetext{
${ }^{27}$ The regional dummy cannot be tested by construction. The income group dummy cannot be included, either, because the sample has little regional variation among high-income countries. Even though these coefficients are excluded from the test restrictions, the test includes a relatively large number of linear hypotheses and tends to generate large test statistics by econometric nature. Thus, the sufficiently large critical value corresponding to the 1 percent significance level is a precaution. Nevertheless, one test employing government effectiveness as a governance variable can still reject the null hypothesis.
} 


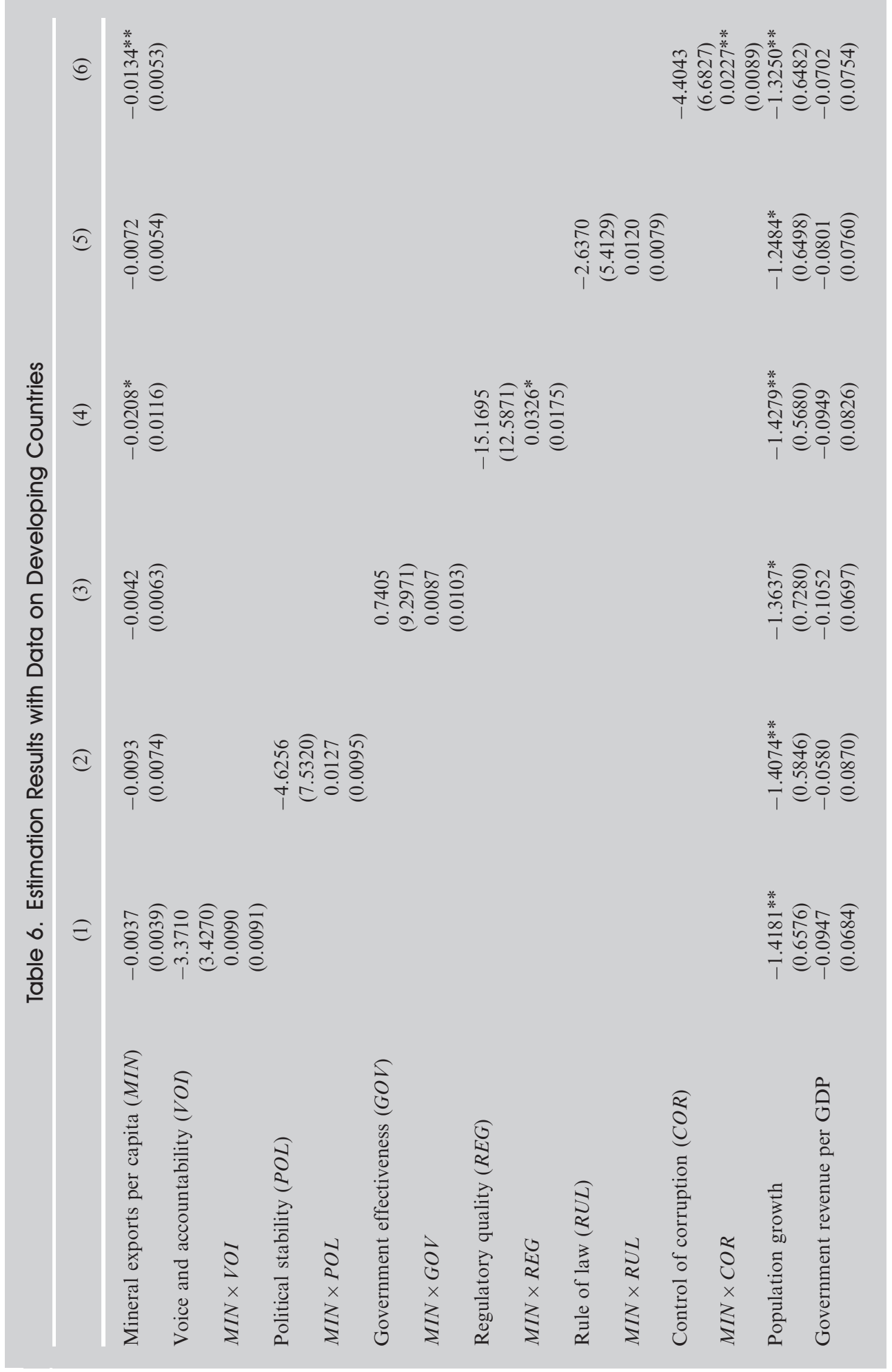




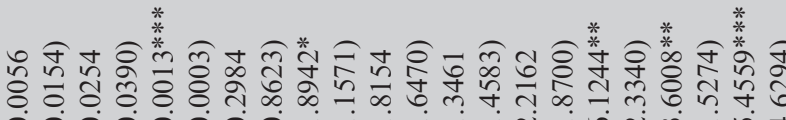

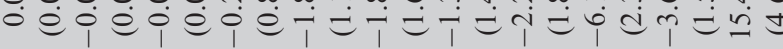

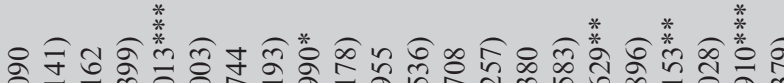

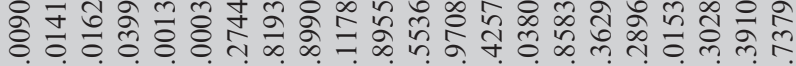

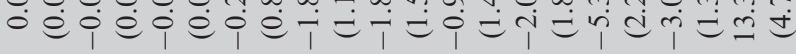

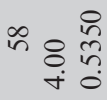

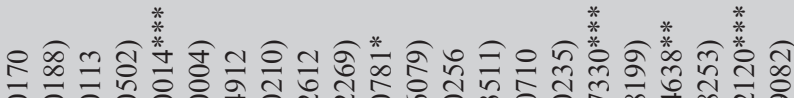

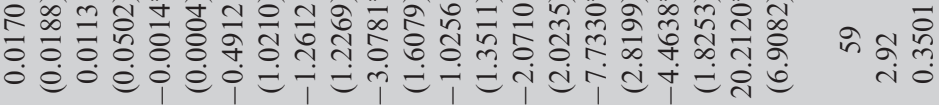

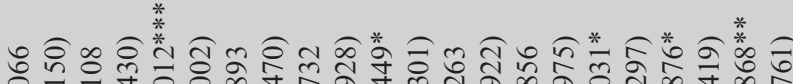

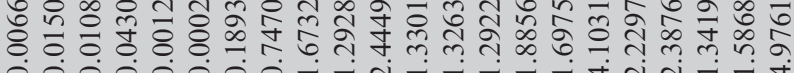
o

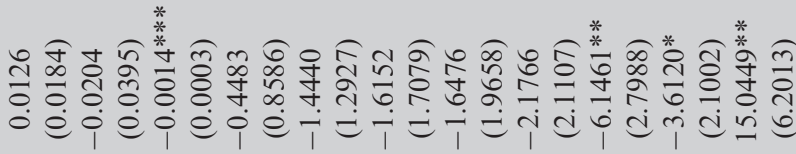

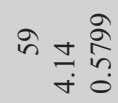

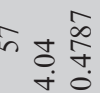

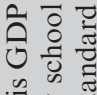

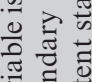
西

西

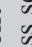

苛

के

$\Xi$ 它范

苛

焉

氙.

군

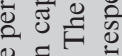

ปี

芯

苂

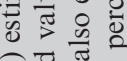

Z

可

․․

를

종 욜

min

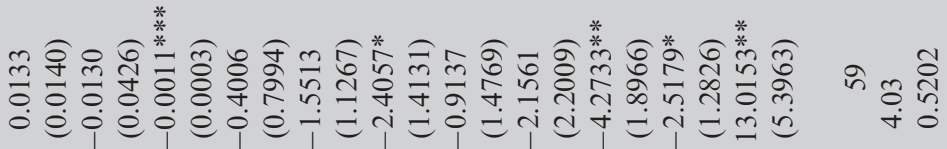

ฮ류

可

寻 预

㱐

is

䲶苛

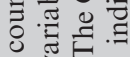

曾

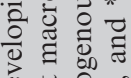

ช 局

त)

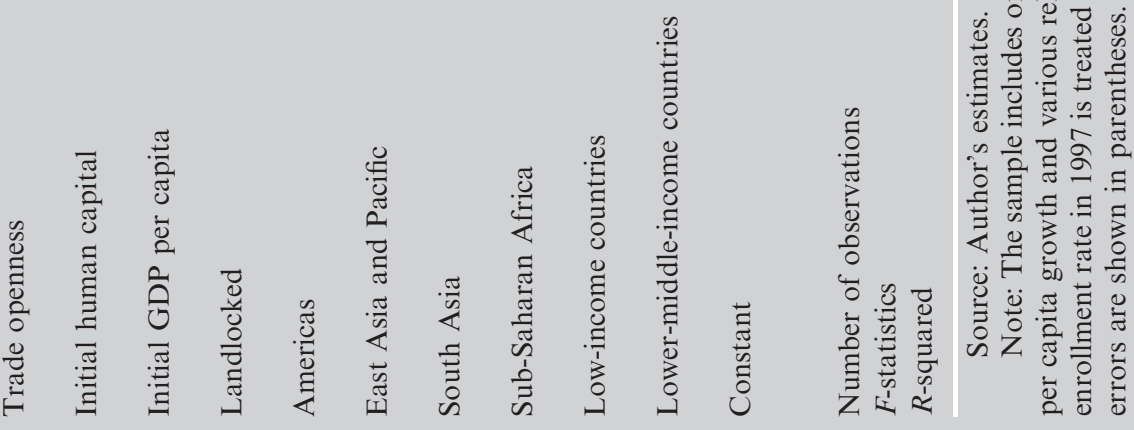


Concurrently, however, the estimation results also indicate that low-income countries tend to record lower GDP growth rates. This means that even after the difference in income levels is controlled, there remains a systematic difference in nonincome growth between low- and middle-income countries. Low-income countries may face institutional and socioeconomic obstacles in achieving high economic development, such as political and macroeconomic instabilities and institutional weaknesses.

\section{Policy Implications}

Given these findings, an important policy question is how to establish effective natural resource management mechanisms in developing countries.

IMF (2005) points out that it is important to introduce explicit fiscal rules for the treatment of mineral revenues. Any windfall should be deposited in a special account and used for designated economic and social development. Chad has actually passed a law to earmark oil revenue for debt service and spending in priority sectors. This type of political step may become a credible and irreversible commitment of the government.

Similarly, disclosure of the terms of contracts and profit-sharing arrangements with natural resource developers and publication of independent external audits have the same effects for increasing transparency in natural resource management. Further, if resource-developing enterprises are privatized, resource extraction must be strictly regulated. Ahmad and Mottu (2002) emphasize the necessity of centralizing resource revenue control and supplementing it with predictable and transparent transfers from the center. Decentralized resource management reduces the capacity of the central government to run countercyclical fiscal policies and to arrange equalization transfers among regions.

Looking at Botswana, there are several lessons and good practices that other resource-rich countries could learn. Botswana has already established the prudent fiscal framework governing ways in which to use mining revenue, but could take further steps to implement more precautionary saving policies for ensuring sustainable and stable growth over the long term. It cannot be overestimated that large market downturns and a depletion of the assets of stabilization funds are always possible (Katz and others, 2004). This is of particular importance for Botswana: because of the country's high prevalence of HIV/AIDS and the related health expenditures, which will increase over the medium term, the fiscal position is expected to tighten increasingly. It is also important to recognize that government mineral revenues are exposed to several uncertain factors. Decomposing changes in government mineral revenue $R$ : exchange rate $E R$, international diamond price $P$, the quantity of diamond exports $Q$, and an average share of export earnings $\theta$, yields the following:

$$
\frac{\Delta R}{R}=\frac{\Delta E R}{E R}+\frac{\Delta P}{P}+\frac{\Delta Q}{Q}+\frac{\Delta \theta}{\theta} .
$$


Table 7. Botswana: Contribution to Changes in Mineral Revenue, 1988-2003 (Percent)

$\begin{array}{lrrrc} & & & & \text { Average Contribution } \\ & 2001 & 2002 & 2003 & 1988-2003 \\ & -7.7 & 0.5 & 8.4 & 100.0 \\ \text { a. Annual change in mineral revenue } & & & & \\ & & & & 27.5 \\ \text { Of which } & 14.3 & 8.5 & -21.8 & 21.3 \\ \text { b. Change in exchange rates (appreciation) } & -7.5 & -12.2 & 12.5 & 19.7 \\ \begin{array}{l}\text { c. Change in international diamond prices } \\ \text { d. Change in diamond export quantities }\end{array} & 6.7 & 8.3 & 7.1 & 31.4 \\ \text { e. Change in other factors (e.g., profit-sharing } & -21.1 & -4.1 & 10.7 & \\ \quad & & & & \end{array}$

Note: Mineral revenue data are available in a series of the central bank's Annual Reports. The annual exchange changes in the exchange rate are calculated from the official exchange rate in the IMF's International Financial Statistics. The international diamond price is measured by the average export value per carat for Botswana, which is the world's largest diamond-producing country. Diamond export value and quantity are also published by the Botswana authorities. The "change in other factors" is defined as a residual left when those three factors are subtracted from the observed mineral revenue change.

An increase in mineral revenue in national currency terms can be explained by: (1) depreciation of the pula, (2) an international price increase, (3) enhancement of production capacity, and (4) other remaining factors captured as changes in the average profit share $(\Delta \theta / \theta){ }^{28}$

As shown in Table 7, 28 percent of changes in mineral revenue are associated with changes in the exchange rate, and 21 percent are attributable to international diamond prices. ${ }^{29}$ Both factors, which are unpredictable, are characterized as windfalls. Resource rents are vulnerable to exogenous shocks, and the necessity of managing resource rents deliberately under a rigid saving mechanism cannot be overemphasized. ${ }^{30}$

\footnotetext{
${ }^{28}$ The underlying rationale for this is $R=\theta[E R(P Q)] . E R$ is defined as the national currency per U.S. dollar and $(P \cdot Q)$ is mineral exports in U.S. dollar terms. $\theta$ mainly reflects the existing profit-sharing arrangements and dividend policies (such as payout ratio, that is, dividends on equity) but also includes possible residual factors unexplained by the other terms, including a measurement error owing to time differences between exports and taxation, as well as changes in the quality mix of diamonds produced.

${ }^{29}$ Mineral revenues fell with the low international market prices in 2002 and the significant currency appreciation in 2003.

${ }^{30}$ In March 2004, the government of Botswana sold half its shares in Anglo American plc., a group company of De Beers, for about 760 million pula ( $\$ 170$ million). This gain was reckoned as part of government mineral revenue and presumably used for general expenditure. However, resource-related asset sales should be discouraged unless long-term revenue is maximized. Debswana is owned in equal shares by the government of Botswana and De Beers Centenary AG, and Anglo American owns 45 percent of De Beers shares through DB Investment. From the long-term perspective, privatization and public asset sales would benefit the economy only if regulation were prudent and transparent.
} 
Given these unavoidable uncertainties, the Botswana government, though having accumulated large assets under a self-disciplinary fiscal rule (for example, SBI) through a series of national development plans, may be able to amplify the governance and resource effects on growth by more explicit insulation of fiscal expenditure from the volatility and uncertainty of mining revenues. For instance, one possible option may be to adopt a nondiamond deficit target rule to accelerate the revenue base diversification, and another is to reserve particular types of resource-related rents (for example, windfalls based on a given medium-term projection of mineral prices) to leave future generations as well off as the current one. This can be complemented by special-account treatment of diamond revenue in the budget.

For increasing transparency, accountability, and predictability in natural resource management, it is in general useful to establish an independent mineral regulatory agency and to disclose and monitor the terms of reference for mining extraction and revenue sharing (Katz and others, 2004). Although the institutional system of the Botswana government appears robust, a more transparent and neutral regulatory agency could advance efficient governance further, with current virtues of good governance maintained. Indeed, the above evidence indicates that in resource management, regulatory quality - which calls on market-friendly competition policies and deregulation - is the most significant of all the dimensions of governance examined above. It is worth recalling that not all mineral projects in which the Botswana government has been extensively involved have been profitable (Gaolathe, 1998). Finally, it is important to keep strengthening anticorruption policies, demonstrably one of the keys to good natural resource management.

\section{Conclusion}

This paper has examined the accepted notion that countries endowed with abundant natural resources grow more slowly than resource-scarce countries, for a number of possible reasons: a strong likelihood of discord and conflicts about resources, Dutch disease, rent seeking, overconfidence, debt overhang, the lack of forward and backward linkages and learning-by-doing effects in the natural resource sector, and social lethargy stemming from the abundance of resources. The big push theory nevertheless predicts that natural resource richness must have a positive effect on economic growth because it provides sufficient financial resources for strengthening economic infrastructure and human capital.

As for the role of governance in transforming resource abundance into economic development, data from 89 countries reveal that an abundance of natural resources does not guarantee growth. What determines the degree to which natural resources can contribute to economic development is governance. Good governance-specifically a strong public voice with accountability, high government effectiveness, good regulation, and 
powerful anticorruption policies - tends to link natural resources with high economic growth. The last two dimensions of governance are especially important for natural resource management in developing countries.

\section{APPENDIX}

\section{Data}

This paper uses data from 89 countries for which the latest macroeconomic statistics, including fiscal and trade data, are available. ${ }^{31}$ The data cover 18 low-income, 22 lowermiddle-income, 19 higher-middle income, and 29 high-income countries; they also cover 19 countries in East Asia and the Pacific and 10 in sub-Saharan Africa. The sample period is from 1998 to $2002 .^{32}$

The dependent variable is the average growth rate of real GDP per capita from 1998 to 2002. Taking the average values is intended to avoid measurement errors owing to short-term economic fluctuations. Unless otherwise indicated, all the macroeconomic data used for this study were taken from the World Bank's World Development Indicators.

Five endogenous variables are taken into account. First, natural resource richness is represented by average natural resource exports for the period, divided by total population. This variable provides good proximity on the assumption that natural resources extracted are mostly exported abroad. The resource export data come from the World Integrated Trade Solution database of the World Bank. Natural resources basically cover oil, nonoil commodities, and precious stones, but not agriculture. Previously (see, for example, Sachs and Warner, 1997; and Papyrakis and Gerlagh, 2004), resource richness has been defined as the share of mineral exports or production in GDP, but this definition is not consistent with the standard growth theory. ${ }^{33}$ The figure of natural resource exports per capita seems more reasonable.

Second, the level of governance affecting resource management is measured by the six governance indicators provided by Kaufmann, Kraay, and Mastruzzi (2003). The indicators are calculated based on existing data sources representing some perceptions of the level of public governance as well as the quality of government policies; they are therefore generally consistent with the general level of governance. This paper uses the 2002 indices normalized between zero and one. ${ }^{34}$

Third, average tax rate is measured by government current revenues, excluding grants, divided by GDP.

${ }^{31} \mathrm{~A}$ full list of sample countries is shown in Appendix Table A.1.

${ }^{32}$ The sample period of three decades taken in the earlier resource-and-growth literature (for example, Sachs and Warner, 1995) seems to be too long to estimate the resource effects in a single equation. Any economic structure might change in a couple of decades. This paper considers five-year economic growth, a conventional duration in the standard growth literature.

${ }^{33}$ These two variables are nevertheless closely related to each other. A simple correlation is 0.7501 in the sample countries.

${ }^{34}$ Kaufmann, Kraay, and Mastruzzi's indices are available for 1996, 1998, 2000, and 2002. This paper uses the 2002 figures, because they are presumed to take time for governance factors to be improved. In fact, the indices generally did not change dramatically during the sample period. The 2002 figures are instrumented by the 1996 data. 
Table A.1. List of Sample Countries

\begin{tabular}{|c|c|}
\hline Americas & Europe and Central Asia \\
\hline Argentina & Albania \\
\hline Bolivia & Austria \\
\hline Brazil & Azerbaijan \\
\hline Canada & Belgium \\
\hline Chile & Bulgaria \\
\hline Colombia & Croatia \\
\hline Costa Rica & Cyprus \\
\hline Dominican Republic & Czech Republic \\
\hline Jamaica & Estonia \\
\hline Mexico & Finland \\
\hline Nicaragua & France \\
\hline Panama & Germany \\
\hline Paraguay & Greece \\
\hline Peru & Hungary \\
\hline United States & Iceland \\
\hline Uruguay & Ireland \\
\hline \multirow{2}{*}{ Venezuela } & Italy \\
\hline & Kyrgyz Republic \\
\hline East Asia and Pacific & Latvia \\
\hline Australia & Lithuania \\
\hline China & Luxembourg \\
\hline Indonesia & Moldova \\
\hline Korea, Rep. & Netherlands \\
\hline Malaysia & Norway \\
\hline Mongolia & Poland \\
\hline New Zealand & Portugal \\
\hline Philippines & Romania \\
\hline Thailand & Russian Federation \\
\hline \multirow[t]{2}{*}{ Vanuatu } & Slovak Republic \\
\hline & Slovenia \\
\hline South Asia & Spain \\
\hline India & Sweden \\
\hline Nepal & Switzerland \\
\hline Pakistan & Turkey \\
\hline Sri Lanka & United Kingdom \\
\hline Sub-Saharan Africa & Middle East and North Africa \\
\hline Botswana & Algeria \\
\hline Burundi & Bahrain \\
\hline Cameroon & Egypt, Arab Rep. \\
\hline Côte d'Ivoire & Israel \\
\hline Ethiopia & Jordan \\
\hline Guinea & Kuwait \\
\hline Kenya & Malta \\
\hline Madagascar & Morocco \\
\hline Mauritius & Oman \\
\hline Senegal & Tunisia \\
\hline Zimbabwe & United Arab Emirates \\
\hline
\end{tabular}


Table A.2. Descriptive Statistics

\begin{tabular}{|c|c|c|c|c|}
\hline Variable & Mean & Standard Deviation & Minimum & Maximum \\
\hline GDP per capita growth & 1.84 & 2.61 & -5.00 & 10.54 \\
\hline Mineral exports per capita & 609.42 & $1,557.60$ & 0.02 & $8,482.77$ \\
\hline Population growth & 1.18 & 1.07 & -0.94 & 5.16 \\
\hline Government revenue per GDP & 25.87 & 9.55 & 3.31 & 44.02 \\
\hline Trade openness & 83.72 & 43.56 & 23.86 & 266.79 \\
\hline Initial human capital & 74.62 & 32.23 & 6.64 & 157.09 \\
\hline Initial GDP per capita & $8,877.06$ & $11,266.93$ & 113.06 & $47,960.78$ \\
\hline Landlocked & 0.20 & 0.41 & 0.00 & 1.00 \\
\hline \multicolumn{5}{|l|}{ Governance indices } \\
\hline Voice and accountability & 0.66 & 0.23 & 0.20 & 1.00 \\
\hline Political stability & 0.63 & 0.25 & 0.05 & 1.00 \\
\hline Government effectiveness & 0.55 & 0.23 & 0.11 & 0.99 \\
\hline Regulatory quality & 0.64 & 0.21 & 0.13 & 1.00 \\
\hline Rule of law & 0.58 & 0.24 & 0.15 & 1.00 \\
\hline Control of corruption & 0.51 & 0.24 & 0.15 & 1.00 \\
\hline \multicolumn{5}{|l|}{ Income group dummy } \\
\hline High-income counties & 0.33 & 0.47 & 0.00 & 1.00 \\
\hline Low-income countries & 0.20 & 0.41 & 0.00 & 1.00 \\
\hline Lower-middle-income countries & 0.25 & 0.44 & 0.00 & 1.00 \\
\hline Upper-middle-income countries & 0.22 & 0.41 & 0.00 & 1.00 \\
\hline \multicolumn{5}{|l|}{ Regional dummy } \\
\hline Americas & 0.19 & 0.40 & 0.00 & 1.00 \\
\hline East Asia and Pacific & 0.11 & 0.32 & 0.00 & 1.00 \\
\hline South Asia & 0.05 & 0.21 & 0.00 & 1.00 \\
\hline Sub-Saharan Africa & 0.13 & 0.33 & 0.00 & 1.00 \\
\hline
\end{tabular}

Fourth, the extent to which trade circumstances are open and liberalized is measured by the ratio of total trade to GDP. Average population growth rate for the period is used for $n$.

Finally, for estimating the indirect growth effects of trade conditions, a terms of trade index (an export price index divided by an import price index), is employed, using the World Economic Outlook database. TOT is defined as a percent change in terms of trade during the five-year period.

The model includes three exogenous control variables. To control for the differences in initial state conditions across countries, this paper uses initial accumulation of human capital and GDP per capita just before the sampling period. The Hausman exogeneity test cannot reject the hypothesis that at minimum these two variables are exogenous. ${ }^{35}$ Initial human capital is measured by the percentage of gross secondary school enrollments compared to the official school-age population in 1997; GDP per capita is

${ }^{35}$ In the Hausman test, the $\chi^{2}$ statistics tend to be estimated at nearly zero. This can be interpreted as strong evidence that the null hypothesis cannot be rejected. 
in U.S. dollar terms for $1997 .{ }^{36}$ Finally, the landlocked dummy variable is adopted to take geographical differences into consideration.

To control unobservable region-specific and income-group-specific characteristics, regional and income-group dummy variables are also included. This treatment is expected to be useful for mitigating the measurement problem inherent in any crosscountry analysis.

Appendix Table A.2 shows the summary statistics. The average growth rate of the sample countries is about 1.8 percent, though there is significant variation, from -5 percent to over 10 percent. The natural resources per capita figure varies widely, from $\$ 0.02$ to over $\$ 8,000$; the mean is $\$ 609$. Population growth also differs considerably in the sample countries. Whereas several countries have population growth of more than 5 percent, some developing countries, such as Bulgaria, have experienced a net reduction in population.

The average tax rate for the sample is about 25 percent. Trade openness differs from 24 percent to 270 percent, implying that some counties, such as Luxembourg and Malaysia, are highly involved in the international trade system and others are not. The initial conditions in terms of human capital and national incomes also show considerable variations. Finally, the sample includes 18 landlocked countries.

\section{REFERENCES}

Acemoglu, D., S. Johnson, and J. Robinson, 2001, "The Colonial Origins of Comparative Development: An Empirical Investigation," American Economic Review, Vol. 91 (December), pp. 1369-401.

— 2002, “An African Success Story: Botswana,” CEPR Discussion Paper No. 3219 (London, Centre for Economic Policy Research).

- 2005, "Institutions as the Fundamental Cause of Long-Run Growth," in Handbook of Economic Growth, Volume 1A, ed. by P. Aghion, and S. Durlauf (Amsterdam, Elsevier).

Ahmad, E., and E. Mottu, 2002, "Oil Revenue Assignments: Country Experiences and Issues," IMF Working Paper 02/203 (Washington, International Monetary Fund).

Angrist, J., and A. Kugler, 2005, "Rural Windfall or a New Resource Curse? Coca, Income, and Civil Conflict in Colombia," NBER Working Paper No. 11219 (Cambridge, Massachusetts, National Bureau of Economic Research).

Auty, R., and D. Evans, 1994, "Trade and Industrial Policy for Sustainable Resource-Based Development: Policy Issues, Achievements and Prospects," UNCTAD Report GE94-50979 (Geneva, United Nations Conference on Trade and Development).

Bacon, R., 2001, "Petroleum Taxes: Trends in Fuel Taxes (and Subsidies) and the Implications," Viewpoint Note Number 240 (Washington, World Bank).

Banerjee, A., and E. Duflo, 2003, "Inequality and Growth: What Can the Data Say?," Journal of Economic Growth, Vol. 8 (September), pp. 267-99.

Barbier, E., R. Damania, and D. Léonard, 2005, "Corruption, Trade and Resource Conversion," Journal of Environmental Economics and Management, Vol. 50 (September), pp. 276-99.

\footnotetext{
${ }^{36}$ For several countries, the 1996 human capital variable is used because data are lacking.
} 
Barro, R., 1990, "Government Spending in a Simple Model of Endogenous Growth," Journal of Political Economy, Vol. 98 (October), pp. S103-S25.

- 1997, Determinants of Economic Growth: A Cross-Country Empirical Study (Cambridge, Massachusetts, MIT Press).

and X. Sala-i-Martin, 1995, Economic Growth (New York, McGraw-Hill).

Bloch, H., and D. Sapsford, 2000, "Whither the Terms of Trade? An Elaboration of the Prebisch-Singer Hypothesis," Cambridge Journal of Economics, Vol. 24 (July), pp. 461-81.

Bloom, D., D. Canning, and J. Sevilla, 2003, “Geography and Poverty Traps," Journal of Economic Growth, Vol. 8 (December), pp. 355-78.

Burnside, C., and D. Dollar, 2000, "Aid, Policies, and Growth," American Economic Review, Vol. 90 (September), pp. 847-68.

Collier, P., and A. Hoeffler, 2005, "Resource Rents, Governance, and Conflict," Journal of Conflict Resolution, Vol. 49 (August), pp. 625-33.

Corden, W., and J. Neary, 1982, "Booming Sector and De-Industrialisation in a Small Open Economy," Economic Journal, Vol. 92 (December), pp. 825-48.

Darity, W., 1990, “The Fundamental Determinants of the Terms of Trade Reconsidered: Long-Run and Long-Period Equilibrium," American Economic Review, Vol. 80 (September), pp. 816-27.

Davis, G., 1995, "Learning to Love the Dutch Disease: Evidence from the Mineral Economies," World Development, Vol. 23 (October), pp. 1765-79.

—, and J. Tilton, 2002, "Should Developing Countries Renounce Mining? A Perspective on the Debate," (unpublished; Golden, Colorado, Colorado School of Mines). Available via the Internet: http://www.icmm.com/uploads/62Tilton Davisfinalversion.pdf.

— and J. Tilton, 2005, “The Resource Curse," Natural Resources Forum, Vol. 29 (August), pp. 233-42.

Davoodi, H., and H. Zou, 1998, "Fiscal Decentralization and Economic Growth: A Cross-Country Study," Journal of Urban Economics, Vol. 43 (March), pp. 244-57.

de Ferranti, D., G. Perry, D. Lederman, and W. Maloney, 2001, From Natural Resources to the Knowledge Economy: Trade and Job Quality (Washington, World Bank).

Devarajan, S., and V. Swarrop, 1998, “The Implications of Foreign Aid Fungibility for Development Assistance,” Policy Research Working Paper No. 2022 (Washington, World Bank).

Easterly, W., R. Levine, and D. Roodman, (2004), "Aid, Policies, and Growth: Comment," American Economic Review, Vol. 94 (June), pp. 774-80.

Farzin, Y.H., 1999, "Optimal Saving Policy for Exhaustible Resource Economies," Journal of Development Economics, Vol. 58 (February), pp. 149-84.

Gaolathe, B., 1998, "Development of Botswana's Mineral Sector," in Aspects of the Botswana Economy: Selected Papers, ed. by J.S. Salkin, D. Mpabanga, D. Cowan, J. Selwe, and M. Wright (Oxford, James Currey Publishers).

Glaeser, E., R. La Porta, F. Lopez-de-Silanes, and A. Shleifer, 2004, "Do Institutions Cause Growth?," Journal of Economic Growth, Vol. 9 (September), pp. 271-303.

Goldberg, V., and J. Erickson, 1987, "Quantity and Price Adjustment in Long-Term Contracts: A Case Study of Petroleum Coke," Journal of Law and Economics, Vol. 30 (October), pp. 369-98. 
Gupta, S., B. Clements, A. Pivovarsky, and E. Tiongson, 2003, "Foreign Aid and Revenue Response: Does the Composition of Aid Matter?," IMF Working Paper 03/ 176 (Washington, International Monetary Fund).

Gylfason, T., 2001, "Natural Resources, Education, and Economic Development," European Economic Review, Vol. 45 (May), pp. 847-59.

— 2006, "Natural Resources and Economic Growth: From Dependence to Diversification," in Economic Liberalization and Integration Policy: Options for Eastern Europe and Russia, ed. by H. Broadman, T. Paas, and P. Welfens (New York, Springer), pp. 201-31.

International Monetary Fund (IMF), 1999, Botswana: Selected Issues and Statistical Appendix, IMF Staff Country Report No. 99/132 (Washington).

—, 2005 Regional Economic Outlook: Sub-Saharan Africa (May 2005) (Washington).

International Telecommunication Union (ITU), 2001, Effective Regulation Case Study: Botswana (Geneva). Available via the Internet: www.bta.org.bw/pubs/bo_ca_st.pdf.

Joskow, P., 1987, "Contract Duration and Relationship-Specific Investments: Empirical Evidence from Coal Markets," American Economic Review, Vol. 77 (March), pp. 168-85.

Katz, M., U. Bartsch, H. Malothra, and M. Cuc, 2004, Lifting the Oil Curse: Improving Petroleum Revenue Management in Sub-Saharan Africa (Washington, International Monetary Fund).

Kaufmann, D., A. Kraay, and A. Mastruzzi, 2003, "Governance Matters III: Governance Indicators for 1996-2002,” Policy Research Working Paper No. 3106 (Washington, World Bank).

Kronenberg, T., 2004, "The Curse of Natural Resources in the Transition Economies," Economics of Transition, Vol. 12 (September), pp. 399-426.

Leamer, E., H. Maul, S. Rodriguez, and P. Schott, 1999, "Does Natural Resource Abundance Increase Latin American Income Inequality?," Journal of Development Economics, Vol. 59 (June), pp. 3-42.

Leite, C., and J. Weidmann, 1999, "Does Mother Nature Corrupt? Natural Resources, Corruption, and Economic Growth," IMF Working Paper 99/85 (Washington, International Monetary Fund).

Maloney, W., 2002, "Missed Opportunities: Innovation and Resource-Based Growth in Latin America," Economia, Vol. 3 (Fall), pp. 111-67.

Mankiw, G., D. Romer, and D. Weil, 1992, "A Contribution to the Empirics of Economic Growth," Quarterly Journal of Economics, Vol. 107 (May), pp. 407-37.

Manzano, O., and R. Rigobon, 2001, "Resource Curse or Debt Overhang?," NBER Working Paper No. 8390 (Cambridge, Massachusetts, National Bureau of Economic Research).

Masten, S., and K. Crocker, 1985, "Efficient Adaptation in Long-Term Contracts: Takeor-Pay Provisions for Natural Gas," American Economic Review, Vol. 75 (December), pp. 1083-93.

Murphy, K., A. Shleifer, and R. Vishny, 2000, "Industrialization and the Big Push," in Readings in Development Economics Vol. 1 (Micro-Theory), ed. by P. Bardhan and C. Udry (Cambridge, Massachusetts: MIT Press). 
Papyrakis, E., and R. Gerlagh, 2004, "The Resource Curse Hypothesis and Its Transmission Channels," Journal of Comparative Economics, Vol. 32 (March), pp. 181-93.

Porter, R., 1995, "The Role of Information in U.S. Offshore Oil and Gas Lease Auctions," Econometrica, Vol. 63 (January), pp. 1-27.

Romer, D., 1996, Advanced Macroeconomics (New York, McGraw-Hill).

Sachs, J., and A. Warner, 1995, "Natural Resource Abundance and Economic Growth," NBER Working Paper No. 5398 (Cambridge, Massachusetts, National Bureau of Economic Research).

- 1997, "Sources of Slow Growth in African Economies," Journal of African Economies, Vol. 6 (October), pp. 335-76.

- 1999, "The Big Push, Natural Resource Booms and Growth," Journal of Development Economics, Vol. 59 (June), pp. 43-76.

_ 2001, "The Curse of Natural Resources," European Economic Review, Vol. 45 (May), pp. 827-38.

Sala-i-Martin, X., and A. Subramanian, 2003, "Addressing the Natural Resource Curse: An Illustration from Nigeria," NBER Working Paper No. 9804 (Cambridge, Massachusetts, National Bureau of Economic Research).

Shahnawaz, S., and J. Nugent, 2004, "Is Natural Resource Wealth Compatible with Good Governance?," Review of Middle East Economics and Finance, Vol. 2 (December), pp. 159-91.

Sørli, M., N. Gleditsch, and H. Strand, 2005, "Why Is There So Much Conflict in the Middle East?," Journal of Conflict Resolution, Vol. 49 (February), pp. 141-65.

Tanzi, V., 1998, "Corruption Around the World," IMF Staff Papers, Vol. 45 (December), pp. 559-94.

— Working Paper 97/139 (Washington, International Monetary Fund).

World Bank, 2004, Doing Business in 2004: Understanding Regulation (Washington, World Bank).

_ 2005, World Development Report 2006: Equity and Development (Washington, World Bank). 